\title{
Response of coastal Antarctic phytoplankton to solar radiation and ammonium manipulation: An in situ mesocosm experiment
}

\author{
Susana Agustí, ${ }^{1}$ Carlos M. Duarte, ${ }^{1}$ Moira Llabrés, ${ }^{1}$ Nona S. R. Agawin, ${ }^{2}$ \\ and Hilary Kennedy ${ }^{3}$ \\ Received 9 April 2008; revised 19 October 2008; accepted 4 November 2008; published 13 February 2009.
}

[1] We tested the role of solar irradiance and ammonium inputs on phytoplankton bloom formation in Antarctic coastal waters $\left(62^{\circ} 39.576^{\prime} \mathrm{S} ; 60^{\circ} 22.408^{\prime} \mathrm{W}\right.$, Livingston Island, South Sethlands) through the combination of a large-scale, in situ mesocosm experiment and a small-scale experiment. Phytoplankton growth, nutrient use, and biomass development remained low at ambient irradiances and increased greatly (greater than thirtyfold) to yield large (up to $93 \mu \mathrm{g}$ chlorophyll a $1^{-1}$ ) phytoplankton blooms in response to moderate shading. The phytoplankton communities tested were light limited when irradiance was reduced below $30 \%$ of the incident irradiance and stressed by high irradiance at the full ambient irradiance. Ammonium additions greatly stimulated phytoplankton growth, biomass, and stimulated the use of the large nitrate pool present in the Antarctic waters and lead to a decline in the specific UV absorption by mycosporinelike amminoacids. The small-scale experiment confirmed the role of UV irradiance in inhibiting phytoplankton growth and the capacity of ammonium inputs to overcome this inhibition. The alleviation of the high-irradiance stress by ammonium additions provided evidence of a key role of ammonium inputs in allowing phytoplankton to resume growth and nutrient use. The results demonstrate that there is a narrow window of irradiance where phytoplankton growth is adequate and that coastal Antarctic phytoplankton communities, examined here, are either light limited or stressed by high irradiance at irradiances outside this range. More research is needed to analyze the interplay between light climate, ammonium, and bloom initiation in Antarctic coastal waters to test the generality of the results obtained.

Citation: Agustí, S., C. M. Duarte, M. Llabrés, N. S. R. Agawin, and H. Kennedy (2009), Response of coastal Antarctic phytoplankton to solar radiation and ammonium manipulation: An in situ mesocosm experiment, J. Geophys. Res., 114, G01009, doi:10.1029/2008JG000753.

\section{Introduction}

[2] Low phytoplankton biomass in the presence of highnutrient concentrations is characteristic of the Southern Ocean [e.g., El-Sayed et al., 1983; Holm-Hansen et al., 1984]. Despite this general situation, large phytoplankton blooms have been reported to occur periodically in Antarctic coastal waters [e.g., El-Sayed et al., 1983; Holm-Hansen et al., 1984; Sullivan et al., 1993; Ducklow et al., 2006], indicating that the limiting factors controlling phytoplankton development are occasionally releaved in these areas. In contrast to the open waters of the Southern Ocean [e.g., De Baar et al., 1995; De Baar and Boyd, 2000], Antarctic coastal waters are likely to be iron sufficient [e.g., Martin et al., 1990], receiving iron transported by large icebergs [Smith et al., 2007], or from volcanic ash that has been

\footnotetext{
${ }^{1}$ Instituto Mediterráneo de Estudios Avanzados, CSIC-UIB, Esporles, Spain.

${ }^{2}$ Department of Biology, University of the Islas Baleares, Palma, Spain

${ }^{3}$ School of Ocean Sciences, Bangor University, Menai Bridge, UK.
}

Copyright 2009 by the American Geophysical Union. 0148-0227/09/2008JG000753 deposited along the Antarctic peninsula area [e.g., SañudoWilhelmy et al., 2002], derived from eruptions at near-by Deception Island (Figure 1). Other processes, related to ice melting dynamics [Moline et al., 2004] or high grazing pressure, have also been identified as factors controlling phytoplankton biomass in Antarctic coastal waters [cf. Boyd, 2002]. Solar radiation is an important limiting resource in coastal areas because of the shading imposed by deep mixing [e.g., Mitchell et al., 1991; Nelson and Smith, 1991], or shading by the presence of glacial flour [Agusti and Duarte, 2000]. Solar radiation is also a stress factor to Antarctic phytoplankton because of the relatively high ultraviolet (UV) radiation incident on Antarctic waters [e.g., Smith et al., 1992; Cullen et al., 1992; Arrigo, 1994]. Hence, irradiance may be often too low or too high to allow phytoplankton nutrient use thus inhibiting phytoplankton blooms in coastal waters. In addition, while nitrate is present at high concentrations in the ambient waters, ammonium concentrations are typically low in the Southern Ocean [Biggs et al., 1985; Bianchi et al., 1997; Priddle et al., 1997]. 


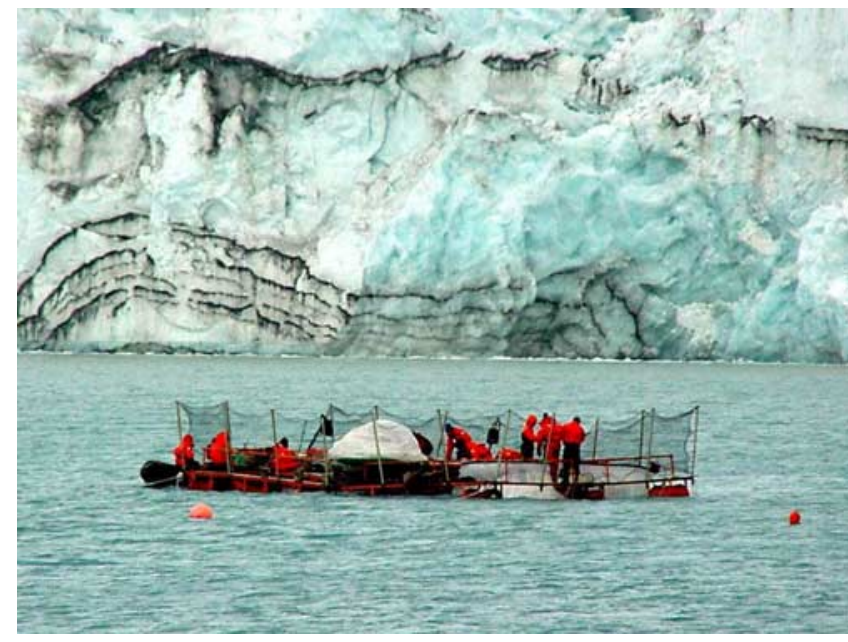

Figure 1. A view of the setting of the deployment of the experimental platform holding the mecosms in Johnson's Dock $\left(62^{\circ} 39.576^{\prime} \mathrm{S} ; 60^{\circ} 22.408^{\prime} \mathrm{W}\right.$, Livingston Island, Antarctica). The dark bands on the glacial are volcanic ash.

[3] Phytoplankton in high-nutrient, low-chlorophyll areas, such as the Southern Ocean, have been reported to show low specific nitrate uptake rates, restricting the presence of phytoplankton blooms [Dugdale and Wilkerson, 1991]. Although nitrate pools may be occasionally depleted [Sweeney et al., 2000], ammonium is rapidly utilized by Antarctic phytoplankton [Biggs et al., 1985; Dugdale and Wilkerson, 1991]. This suggests the possibility that phytoplankton blooming in iron-rich coastal Antarctic waters may also be dependent on ammonium supply and is consistent with the results of a pilot mesocosm experiment enclosing a coastal Antarctic phytoplankton community, where a large phytoplankton bloom developed following the initial addition of ammonium [Agusti and Duarte, 2000].

[4] Large-scale experiments have proved to be instrumental in testing hypotheses regarding the regulation of phytoplankton production in the Southern Ocean, as demonstrated by experimental iron additions to parcels of open water [e.g., Boyd et al., 2000; Gervais et al., 2002]. However, these large-scale perturbation experiments cannot be used to test the role of multiple limiting factors or stressors, since typically only one parcel of water can be manipulated [e.g., Boyd et al., 2000; Gervais et al., 2002], and the manipulation of resources individually or together, is cumbersome or impossible. Other approaches to largescale experiments, such as large $\left(>10 \mathrm{~m}^{3}\right)$ mesocosms experiments have been successfully used elsewhere to test hypotheses on the control of planktonic communities [Duarte et al., 1997], but have not been attempted in Antarctic waters, although recent studies have demonstrated the feasibility of conducting such experiments [Agusti and Duarte, 2000].

[5] Here we use two subsequent series of experiments to examine the role of irradiance and ammonium inputs on phytoplankton bloom formation in Antarctic coastal waters. The first experiment consisted of a large-scale mesocosm experiment, the Estímulo Experimental de la Producción Antártica Costera (ESEPAC) experiment, which used a duplicated series of four large $\left(20 \mathrm{~m}^{3}\right)$ mesocosms, each exposed to a range of irradiances (from $100 \%$ to $5 \%$ of the ambient level), where one of the series received daily additions of phosphate, silicate and ammonium. The subsequent small-scale ( $2 \mathrm{~L}$ units) experiment, also undertaken in Antarctic waters, was used to verify the results from the previous mesocosm experiment. One objective of the ESEPAC mesocosm experiment was to test the role of high irradiance in suppressing phytoplankton growth. A second objective was to test the notion that a phytoplankton bloom can be induced at full ambient irradiance, following an ammonium pulse. This latter objective was followed on from inferences made during a previous pilot experiment, which tested the feasibility of conducting large-scale mesocosm experiments in Antarctic waters [Agustí and Duarte, 2000]. Because large-scale mesocosm experiments cannot be entirely controlled, we planned and conducted a subsequent small-scale experiment to verify the results derived from the ESEPAC mesocosm experiment. In particular, we compared the growth response of phytoplankton exposed to the full spectrum of irradiance, across a range of incoming irradiance to that of phytoplankton experiencing a reduced exposure to UV irradiance. We also tested whether ammonium inputs altered the phytoplankton's response to exposure from the full spectrum of irradiance.

\section{Methods}

\subsection{ESEPAC: Experimental Design}

[6] The ESEPAC experiment was conducted in Johnson's Dock $\left(62^{\circ} 39.576^{\prime} \mathrm{S} ; 60^{\circ} 22.408^{\prime} \mathrm{W}\right.$, Livingston Island, Antarctica), a sheltered bay receiving glacial melt containing iron-rich volcanic ash (Figure 1) [Agusti and Duarte, 2000]. A floating platform holding eight mesocosms, consisting of large (14 m tall, $2.3 \mathrm{~m}$ diameter) chemically UV-stabilized polyethylene bags, was moored in the deepest sector of the bay (about $25 \mathrm{~m}$ ) on 21 January 2000 (Figure 1). The mesocosms were filled with ambient, unscreened water (from a depth range of $0.5-3 \mathrm{~m}$ ), first by inmersion of the bags and subsequently using water pumps, on 23 January 2000. The bags were not completely filled to their maximum capacity of $35 \mathrm{~m}^{3}$ to allow propagation of turbulence across the flexible walls, resulting in an average volume of $20 \mathrm{~m}^{3}$ in the mesocosms. Hence, no additional efforts were made to provide additional mixing. The natural communities enclosed included grazers (mainly copepods, salps and amphipods) at concentrations comparable to those in the ambient waters. The experiment, divided into two phases, was conducted over a period of 25 days. Two mesocosms received the full ambient irradiance and divers covered the outer surface and top of the remaining duplicate mesocosms, down to a depth of $10 \mathrm{~m}$ with neutral screens that transmitted 50,25 , and $10 \%$ of the natural irradiance (Table 1). The actual shading imposed was verified from daily water column irradiance measurements using a Seabird conductivity-temperature-depth (CTD) fitted with a photosynthetically active radiation (PAR) sensor. The effective reduction in irradiance within the mesocosms deviated somewhat from the targeted values, and also differed considerably between mesocosms assigned to receive the same irradiance (Figure 1 and Table 1). These effects were due to the presence of folds in the screening material, heterogeneity 
Table 1. Experimental Conditions During Phases I and II and the Average, Standard Error, and Maximum Integrated Chlorophyll $a$ Concentration, Maximum Nutrient Concentration, and the Average Net Growth Rate ${ }^{\mathrm{a}}$

\begin{tabular}{|c|c|c|c|c|c|c|c|c|}
\hline \multicolumn{2}{|c|}{$\begin{array}{c}\text { Ambient } \\
\text { Irradiance }(\%)\end{array}$} & \multirow{2}{*}{$\begin{array}{l}\text { Nutrient } \\
\text { Inputs }\end{array}$} & \multicolumn{2}{|c|}{$\begin{array}{l}\text { Chlorophyll } a \\
\text { Concentration } \\
\left(\mathrm{mg} \mathrm{m}^{-3}\right)\end{array}$} & \multirow{2}{*}{$\begin{array}{l}\text { Ammonium } \\
\text { Concentration } \\
\text { Maximum } \\
\left(\mu \mathrm{mol} \mathrm{L}^{-1}\right)\end{array}$} & \multirow{2}{*}{$\begin{array}{l}\text { Nitrate Concentration } \\
\text { Maximum } \\
(\mu \mathrm{mol} \mathrm{L}-1)\end{array}$} & \multirow{2}{*}{$\begin{array}{c}\text { Phosphate } \\
\text { Concentration } \\
\text { Maximum } \\
\left(\mu \mathrm{mol} \mathrm{L}^{-1}\right)\end{array}$} & \multirow{2}{*}{$\begin{array}{l}\text { Net Growth } \\
\left(\text { day }^{-1}\right)\end{array}$} \\
\hline Nominal & Measured & & Mean & Maximum & & & & \\
\hline \multicolumn{9}{|c|}{ Phase I (Days 0-15) } \\
\hline 100 & 100 & unamended & $1.58 \pm 0.07$ & 2.82 & 0.90 & 33.69 & 2.07 & 0.08 \\
\hline 50 & 39.40 & unamended & $18.33 \pm 5.23$ & 68.76 & 0.80 & 28.62 & 2.13 & $0.20 \pm 0.02$ \\
\hline 25 & 14.30 & unamended & $1.68 \pm 0.08$ & 3.73 & 0.90 & 30.49 & 2.25 & $0.16 \pm 0.02$ \\
\hline 10 & 11.50 & unamended & $0.56 \pm 0.03$ & 0.91 & 1.01 & 31.82 & 2.19 & 0 \\
\hline 100 & 100 & $+\mathrm{NH}_{4}, \mathrm{PO}_{4}, \mathrm{Si}$ & $31.13 \pm 7.56$ & 93.47 & 8.60 & 30.69 & 4.65 & $0.64 \pm 0.18$ \\
\hline 50 & 47.50 & $+\mathrm{NH}_{4}, \mathrm{PO}_{4}, \mathrm{Si}$ & $5.51 \pm 1.09$ & 15.85 & 11.50 & 30.50 & 5.14 & $0.18 \pm 0.01$ \\
\hline 25 & 17.30 & $+\mathrm{NH}_{4}, \mathrm{PO}_{4}, \mathrm{Si}$ & $1.03 \pm 0.03$ & 1.64 & 9.90 & 30.71 & 4.38 & 0.04 \\
\hline 10 & 6.50 & $+\mathrm{NH}_{4}, \mathrm{PO}_{4}, \mathrm{Si}$ & $1.75 \pm 0.18$ & 3.42 & 10.70 & 30.97 & 5.12 & $0.12 \pm 0.03$ \\
\hline \multicolumn{9}{|c|}{ Phase II (Days 16-25) } \\
\hline 100 & unchanged & $+\mathrm{NH}_{4}$ & & 10.7 & & & & $0.35 \pm 0.07$ \\
\hline 50 & unchanged & unchanged & & & & & & \\
\hline 25 & 100 & unchanged & & 21.75 & & & & $0.68 \pm 0.04$ \\
\hline 10 & unchanged & unchanged & & & & & & \\
\hline 100 & unchanged & unchanged & & & & & & \\
\hline 50 & unchanged & unchanged & & & & & & \\
\hline 25 & 100 & unchanged & & 19 & & & & $0.33 \pm 0.07$ \\
\hline 10 & unchanged & unchanged & & & & & & \\
\hline
\end{tabular}

${ }^{\mathrm{a}}$ Maximum integrated Chlorophyll $a$ concentration at $0-13 \mathrm{~m}$; average net growth rate is $\pm \mathrm{SE}$.

on the shading screen and the position of the units on the platform. (Figure 2 and Table 1). Accordingly, subsequent analyses used the actual initial percent shading as the best indication of the shading imposed. One of the series of four duplicate mesocosms was amended with $\mathrm{Si}, \mathrm{P}$, and $\mathrm{N}$ in the form of ammonium, while the other series remained unammended. On the basis of the experience gained during a pilot experiment [Agusti and Duarte, 2000], the nutrientamended mesocosms received a daily addition of 0.1 moles $\mathrm{N}$ (as $\mathrm{NH}_{4} \mathrm{Cl}$ ), $0.1 \mathrm{~mol} \mathrm{Si} \mathrm{(as} \mathrm{F}_{6} \mathrm{Na}_{2} \mathrm{Si}$ ), and $0.01 \mathrm{~mol} \mathrm{P}$ (as $\mathrm{KH}_{2} \mathrm{PO}_{4}$ ). Nutrient amendments were made immediately after sample collection and CTD casts, using previously described procedures [Agusti and Duarte, 2000]. Time series (5 min. intervals) analysis of nutrient concentrations in surface waters following nutrient additions (see below) showed that mixing was achieved within 15 min. Iron additions were unnecessary because iron concentrations are relatively high in the coastal environment [Martin et al., 1990; De Baar and Boyd, 2000; Sañudo-Wilhelmy et al., 2002]. In our study area, which receives inputs of glacial materials containing iron-rich volcanic ash derived from eruptions at near-by Deception Island (Figure 1), iron concentrations in a stream delivering runoff from the Johnson Glacial into the bay have been measured as $0.6 \mu \mathrm{mol} \mathrm{Fe} \mathrm{L}-1$ (A. Tovar-Sánchez, unpublished results, 2005), orders of magnitude above the values of $0.1 \mathrm{nmol} \mathrm{Fe} \mathrm{L}{ }^{-1}$ characteristic of Fe-limited areas of the Southern Ocean. Nutrient additions were discontinued when ammonium concentrations approached $10 \mu \mathrm{M}$ to avoid potentially toxic levels, and were resumed when concentrations declined below this threshold. To further test the effect of ammonium and highirradiance stress on the observed responses, a second phase of the experiment was initiated 16 days after the beginning of the overall experiment, once the responses to the initial treatments imposed had been established. In the second phase, the shading screens of the mesocosms receiving $25 \%$ of the ambient irradiance were removed by divers, exposing them to the full ambient irradiance and daily ammonium additions were initiated to the unamended mesocosm. Daily ammonium additions were also initiated in the unamended mesocosm receiving the full irradiance (Table 1). The responses to the changes in experimental treatments were followed for 9 days.

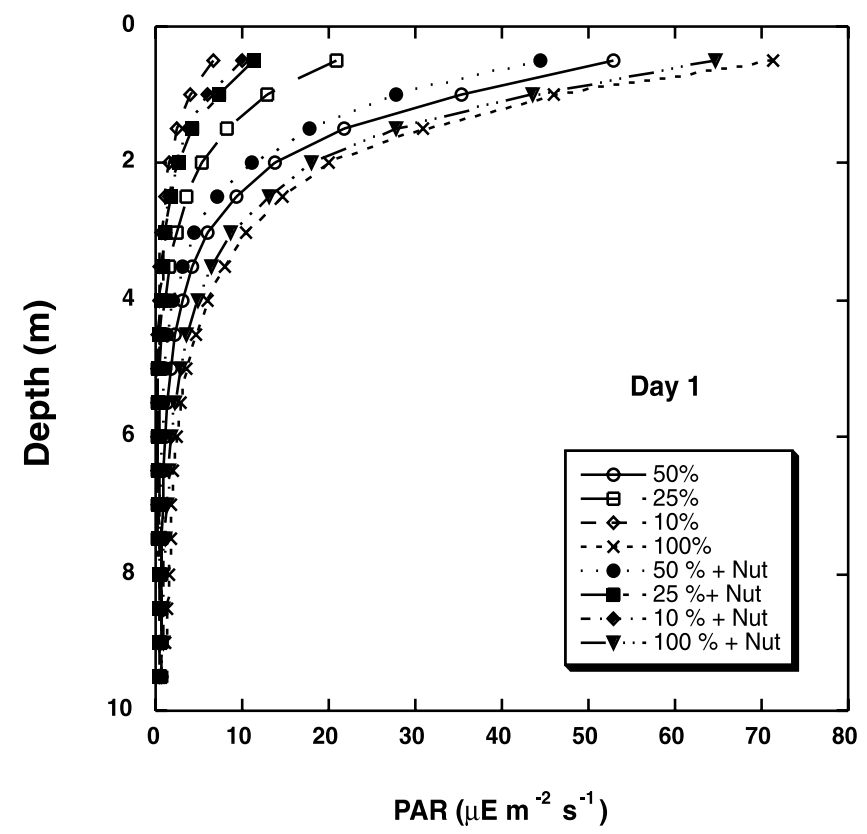

Figure 2. Photosynthetically active irradiance profiles in the mesocosms. The profiles were obtained at 0945 local time on day 1 of the experiment once the shading screens were placed but before any phytoplankton response occurred. The differences in irradiance penetration with depth reflect, therefore, the effect of the shading screens. 


\subsection{Small-Scale Experiment Design}

[7] A small-scale experiment was also conducted in the Spanish Antarctic Base (Livingston Island, Shetland Islands, Antarctica) from 11 February to 19 February 2004. Surface seawater samples were collected from Johnson's Dock and were incubated in quartz and polycarbonate bottles (2 L) submersed in $2000 \mathrm{~L}$ incubators that were placed close to the beach of Sur Bay (Livingston Island). The area was free of shadows, receiving natural incident solar radiation and a pump system recirculated sea-surface water from the bay to the incubator, to maintain in situ temperature. Bottles were acid cleaned and seawater samples were screened through a $150 \mu \mathrm{m}$ net to remove grazers. Quartz bottles allowed all the solar radiation spectra (UVR + PAR) to penetrate the bottles, while polycarbonate bottles allowed PAR radiation to pass through, but filtered out UVB and UVA radiation. Three levels of radiation, corresponding to the 100,57 , and $23 \%$ of the incident irradiance were tested. The 57 and 23\% radiation levels were attained by covering the bottles with a neutral screen and the $100 \%$ radiation treatment was run without screens. At the beginning of the experiment ammonium was added to replicated quartz and polycarbonate bottles to a final concentration of $4.5 \mu \mathrm{M}$, while other replicated bottles acted as a blanks (i.e., without ammonium additions). The total duration of the experiment was 8 days and duplicate samples were taken from each treatment every 2 days to determine chlorophyll $a$ concentration and abundance of the dominant phytoplankton groups.

\subsection{Sampling and Analytical Procedures}

[8] In the ESEPAC experiment integrated $(0-12 \mathrm{~m})$ water samples were collected daily for nutrient concentration and other analysis (chlorophyll a, phytoplankton abundance, light absorption by phytoplankton, among others). Sampling for each parameter was made after different time intervals, but all samples were collected at about 0900 local time, prior to nutrient additions. Integrated samples were obtained by slowly deploying a $12 \mathrm{~m}$ long cylindrical tube that had been previously rinsed with external waters. To retrieve the sample, the tube was capped and then inverted so that the bottom of the tube was recovered first, thereby holding the $12 \mathrm{~m}$ water column inside. Additional integrated samples were collected, following nutrient additions and after sufficient time (about $30 \mathrm{~min}$ ) for mixing to occur. To ensure adequate mixing, nutrient additions were made by filling a tube, extending from the water surface to the bottom of the mesocosms, adding the nutrient solution to the tube waters and withdrawing the tube slowly so as to release the nutrient solution throughout the water column and ensure a homogeneous distribution [Agusti and Duarte, 2000]. Vertical profiles of phytoplankton distribution were derived from daily fluorescence profiles obtained using a fluorescence sensor mounted on the CTD. Samples for the determination of the concentrations of dissolved inorganic phosphate, and nitrate + nitrite were processed immediately or kept frozen until analyzed following standard spectrophotometric methods [Hansen and Koroleff, 1999]. Ammonium concentrations were measured spectrofluorometrically in both experiments [Kérouel and Aminot, 1997] within $1 \mathrm{~h}$ from collection.
[9] In the ESEPAC experiment chlorophyll $a$ concentration was analyzed every 2 out of 3 days, resulting in 17-18 sampling events during the experiment. In the small-scale experiment chlorophyll $a$ concentration was determined every 2 days in all the treatments and replicates, resulting in 5 sampling events along the experiment. A variable water volume ( 25 to $250 \mathrm{ml}$, depending on phytoplankton biomass) was filtered through Whatman GF/F filters for fluorometric analysis of chlorophyll a concentration [Parsons et al., 1984]. Net phytoplankton growth rates $\left(\mu\right.$, days $\left.{ }^{-1}\right)$ were calculated from the slope of least squares linear regressions of the natural log of chlorophyll a over time over the period of growth

$$
\ln \operatorname{Chl} a\left(\mathrm{mg} \mathrm{m}^{-3}\right)=a+\mu \text { time (days) }
$$

or over the entire time series if no clear growth period could be identified. Grazing rates by metazoan zooplankton remained low throughout the ESEPAC experiment (S. Hernández-León, unpublished results, 2000).

[10] For the ESEPAC experiment, net nutrient uptake rates $\left(u, \mu \mathrm{M} \mathrm{d}^{-1}\right)$ were estimated from the reduction in their concentration over the $24 \mathrm{~h}$. period following nutrient additions, and, for mesocosms not receiving any nutrient inputs, from the slope of least squares linear regressions of nutrient concentrations over time,

$$
\text { nutrient }(\mu \mathrm{M})=a+u \text { time }(\text { days })
$$

[11] In the ESEPAC experiment the abundance of autotrophic plankton was estimated using epifluorescence microscopy for pico- and nanophytoplankton. Samples were preserved in glutaraldehyde ( $1 \%$ final concentration) and filtered onto $0.6 \mu \mathrm{m}$ Nuclepore filters and the cells were counted and measured at $\times 1000$ magnification under an Olympus epifluorescence microscope. Samples for microphytoplankton counts $(0.5-2 \mathrm{~L}$, depending on density) were preconcentrated using a Millipore concentrator chamber ( $5 \mu \mathrm{m}$ mesh size), and enumerated and counted at $\times 200$ and $\times 320$ magnification under a Zeiss inverted microscope. Cell volume was calculated microscopically from measurements of the linear dimensions of at least 30 cells in each taxon. Phytoplankton were grouped according to cell diameter $(d)$ into pico- $(d \leq 2 \mu \mathrm{m})$, nano- $(2 \mu \mathrm{m}<d \leq$ $20 \mu \mathrm{m})$, and micro- $(d>20 \mu \mathrm{m})$ size classes. Phytoplankton biovolume was obtained as the product of cell abundance and the cell volume. In the small-scale experiment, nano- and microphytoplankton abundance was determined using epifluorescence microscopy. Samples were preserved in glutaraldehyde ( $1 \%$ final concentration), filtered onto $0.6 \mu \mathrm{m}$ Nuclepore filters and kept frozen $\left(-80^{\circ} \mathrm{C}\right)$ until examination. Cells were counted at $\times 400$ and $\times 1000$ magnification under a Zeiss epifluorescence microscope. The phytoplankton cells that had been counted were differentiated into major taxonomic groups (diatoms and flagellates).

[12] In the samples of the ESEPAC experiment phytoplankton light absorption ( $\left.\mathrm{m}^{-1}, 300-750 \mathrm{~nm}\right)$ was calculated from spectrophotometrically measured absorption coefficients of particles collected on Whatman GF/F filters, and corrected for the absorption of nonalgal particles [Agusti and Duarte, 2000]. The absorption peaks at 

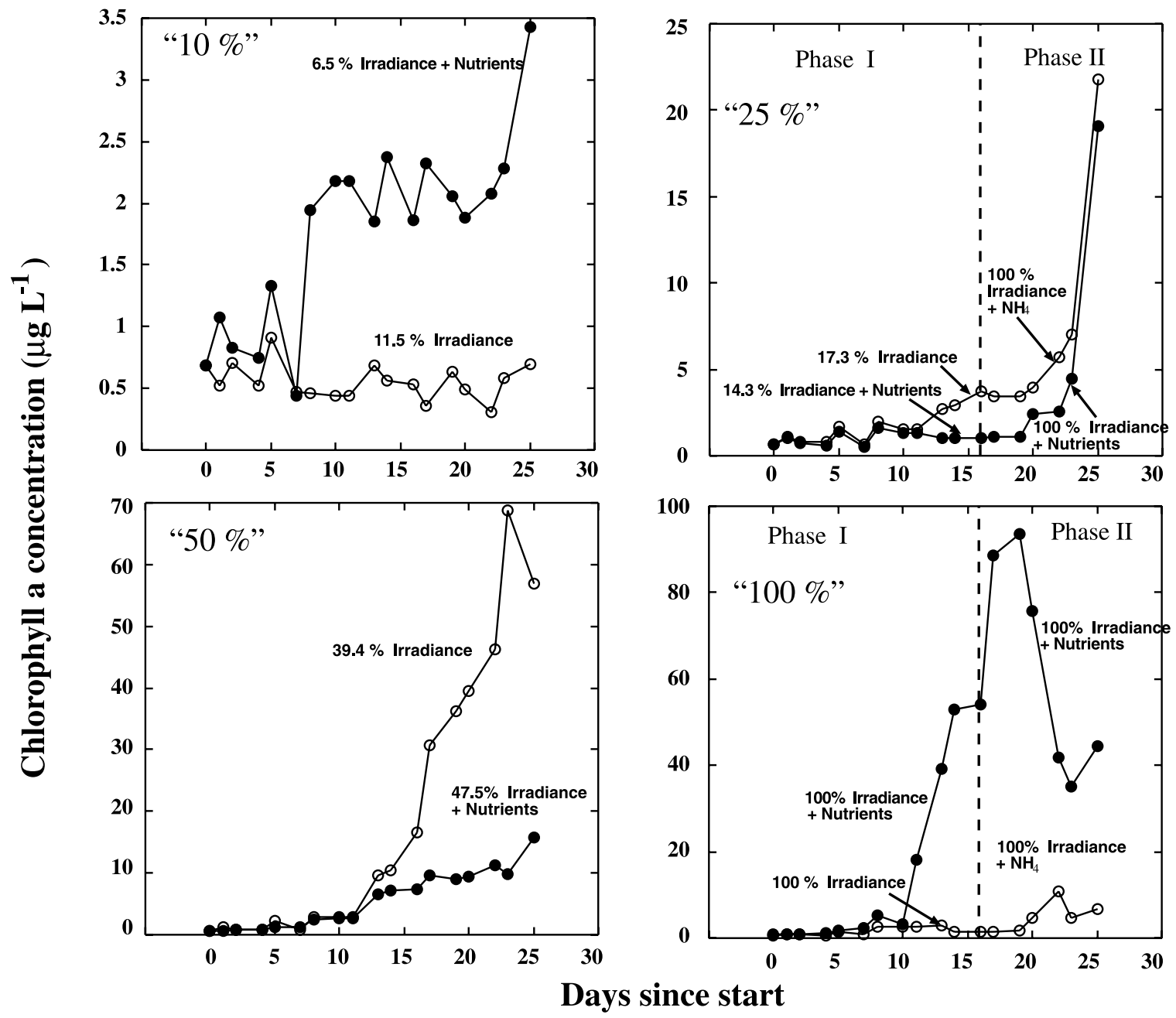

Figure 3. The time series of chlorophyll $a$ concentration in each of the mesocosms. The time series of chlorophyll $a$ concentration in pairs of mesocosms, unamended and receiving nutrient inputs, receiving comparable shading treatments, as indicated by the labels associated to each line. The timing of changes in experimental conditions in a second phase of the experiment are indicated by a vertical dotted line when necessary.

$330 \mathrm{~nm}$ and $675 \mathrm{~nm}$ were used to characterize the light absorption by UV-absorbing mycosporine-like amino acids (MAAs), [Riegger and Robinson, 1997] and chlorophyll $a$, respectively. MAAs are the most commonly encountered UVR-absorbing compounds in aquatic organisms, and have the function of photoprotection against UV radiation by their high absorptivity in the range 309-360 nm [Roy, 2000; Banaszak, 2003]. UV radiation has been found to be most efficient in eliciting increases in cellular MAAs, therefore their presence indicates UV stress [Roy, 2000; Hernando et al., 2002; Banaszak, 2003]. High irradiance may also possibly increase cellular MAAs, and absorption at $330 \mathrm{~nm}$ has been used as an indicator of high-irradiance stress in this study.

[13] To further test the hypothesized effect of ammonium in alleviating high-irradiance stress, primary production was determined in the mesocosm exposed to the full irradiance $100 \%$ ambient light before (phase 1) and after ammonium additions (phase 2). Twelve $125 \mathrm{~mL}$ polycarbonate Nalgene bottles were dispensed each with $120 \mathrm{~mL}$ of water from the mesocosm and one $\mathrm{mL}$ of ${ }^{14} \mathrm{C}$ solution $(10$ to $20 \mu \mathrm{Ci})$ was added to each bottle. Duplicate bottles were suspended at different depths inside the mesocosm units to achieve 13, $21,47,68$, and $100 \%$ (surface) ambient light level of each individual mesocosm. Duplicate dark bottles were also suspended inside the mesocosms. All bottles were incubated for $3 \mathrm{~h}$ in situ, and immediately wrapped in dark plastic bags and brought back to the ship for further processing. The particulate fraction was collected onto $0.45 \mu \mathrm{m}$ Millipore filters, and the filters were fumed over concentrated $\mathrm{HCl}$ to remove traces of inorganic C. Radioactivity on the filters was measured with a liquid scintillation counter with correction for quenching. All materials were acid cleaned prior to use.

[14] Solar radiation during the time of the experiments was automatically recorded by a meteorological station located in the Spanish Antarctic Base Juan Carlos I in Livingston Island. The station was provided with a Kipp and Zonen radiometer CUV3 for UVB + UVA (300-400 nm) measurements and a YES (Yankee Environmental systems 

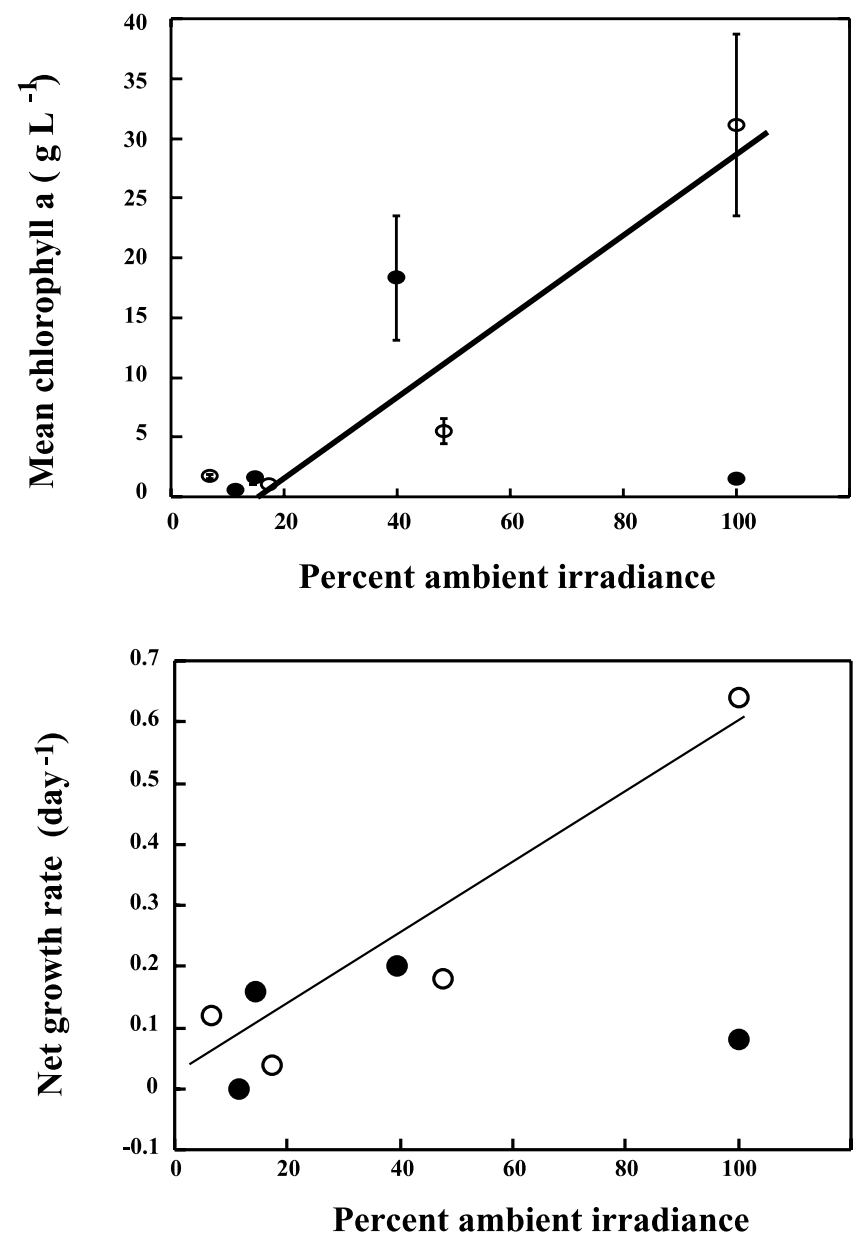

Figure 4. The relationship between the incident irradiance, as a percent of the ambient irradiance, and the average chlorophyll $a$ concentration and the net growth rate of the experimental phytoplankton communities in mesocosms unamended (solid circles) and receiving nutrient inputs (open circles). The solid line shows the fitted regression line for the mesocosms receiving nutrient inputs. Error bars encompass \pm 1 SE.

Inc) UVB-1 radiometer was used to measure only UVB (280-330 nm). The meteorological station also had a Kipp and Zonen CM11 radiometer for the measurement of total solar radiation $(305-2800 \mathrm{~nm})$.

\section{Results}

[15] Weather conditions were variable during the 25 days of the ESEPAC experiment (mean $\pm \mathrm{SE}$ global radiation $=$ $13,700 \pm 970 \mathrm{KJ} \mathrm{m}^{-2} \mathrm{~d}^{-1}$, maximum $=24,482 \mathrm{KJ} \mathrm{m}^{-2}$ $\mathrm{d}^{-1}$ ), but incident irradiance levels were periodically high both during and just before (preceding week mean global radiation $19,900 \mathrm{KJ} \mathrm{m}^{-2} \mathrm{~d}^{-1}$ ) the experiment due to the absence of clouds. The UVA + B radiation $(290-400 \mathrm{~nm})$ contributed, on average $6 \%$ of global radiation, and often exceeded the levels reported to significantly reduce phytoplankton growth [e.g., Karentz et al., 1991]. The maximum daily subsurface $(0.5 \mathrm{~m})$ photosynthetically active irradiance in the mesocosms receiving full ambient irradiance ranged from between 80 and $360 \mu \mathrm{E} \mathrm{m} \mathrm{m}^{-2} \mathrm{~s}^{-1}$, averaging $260 \mu \mathrm{E} \mathrm{m}^{-2} \mathrm{~s}^{-1}$. The light extinction coefficient (PAR) averaged $0.35 \mathrm{~m}^{-1}$ at the onset of the experiment, but the incident irradiance with depth varied greatly in response to the shading imposed on each individual mesocosm (Figure 2). After the start of the experiment the light extinction coefficient changed, first because of sedimentation of the glacial flour inside the mesocosms and second because of phytoplankton development within the mesocosms. Thus only initial shading levels directly reflect those experimentally imposed. In the most shaded mesocosms the average light extinction coefficient $\left(0.39 \pm 0.03 \mathrm{~m}^{-1}\right)$, was comparable to that in the ambient waters. The average light extinction coefficient increased by, on average, 39 to $50 \%$ in the remaining mesocosms, with the nutrient-ammended mesocom exposed to full irradiance showing the highest average light extinction coefficient along the experiment $(0.58 \pm$ $\left.0.04 \mathrm{~m}^{-1}\right)$. Water temperature ranged between 1.5 and $1.9^{\circ} \mathrm{C}$ throughout the water column for the duration of the study. The water column was well mixed down to $4.5 \mathrm{~m}$, where there was a weak pycnoclyne, these conditions were replicated in all the mesocosms within 1 day from their deployment.

[16] Initial nutrient concentrations in the ambient waters were very high $(1.6 \mu \mathrm{M}$ phosphate, $27.5 \mu \mathrm{M}$ nitrate, and $30 \mu \mathrm{M}$ silicate), while ammonium concentration was much lower $(0.6 \mu \mathrm{M})$. Through nutrient additions, ammonium accumulated in all of the amended mesocosms (Table 1), although at rates lower than addition rates, indicating ammonium uptake. Once nutrient additions were discontinued, as concentrations approached the upper ceiling of $10 \mu \mathrm{M}$, ammonium concentrations declined in all amended mesocosms, even the one receiving only $10 \%$ irradiance.. Phosphate concentrations also declined following discontinuation of nutrient additions, with a moderate declining trend present in all of the unamended mesocosms receiving $25 \%$ irradiance or higher.

[17] Phytoplankton biomass was low (chlorophyll a concentration $0.69 \mu \mathrm{g} \mathrm{L}^{-1}$ ) at the onset of the experiment, and the community was dominated by picoeukaryots $(69 \%$ biovolume), and large diatoms (30\% of biovolume). Phytoplankton responded to the experimental treatment after a lag phase of 7 to 10 days (Figure 3). Differences in the duration of the lag phase led to differences in phytoplankton biomass, for instance the phytoplankton community in the mesocosm amended with nutrients and with a nominal shading of $50 \%$ showed a shorter lag phase relative to that in the unamended mesocosm, leading to a major difference in chlorophyll a development (Figure 3 ) despite comparable growth rates over the active growth period (Table 1). The average phytoplankton biomass increased linearly with the percentage average irradiance experienced by the phytoplankton, independently of nutrient inputs, up to levels corresponding to half the ambient irradiance (Table 1 and Figure 4). This trend is not continued in the unamended mesocosm receiving the full ambient irradiance, which reached a biomass well below those of the moderately shaded mesocosms (Table 1 and Figures 2 and 3). In contrast, the nutrient-amended mesocosms exposed to the full incident irradiance exceptionally high concentrations for chlorophyll $a$ were recorded (up to $93.47 \mu \mathrm{g} \mathrm{L}^{-1}$, yielding an integrated pool of $1215 \mathrm{mg}$ Chlorophyll $a \mathrm{~m}^{-2}$, Table 1 and 

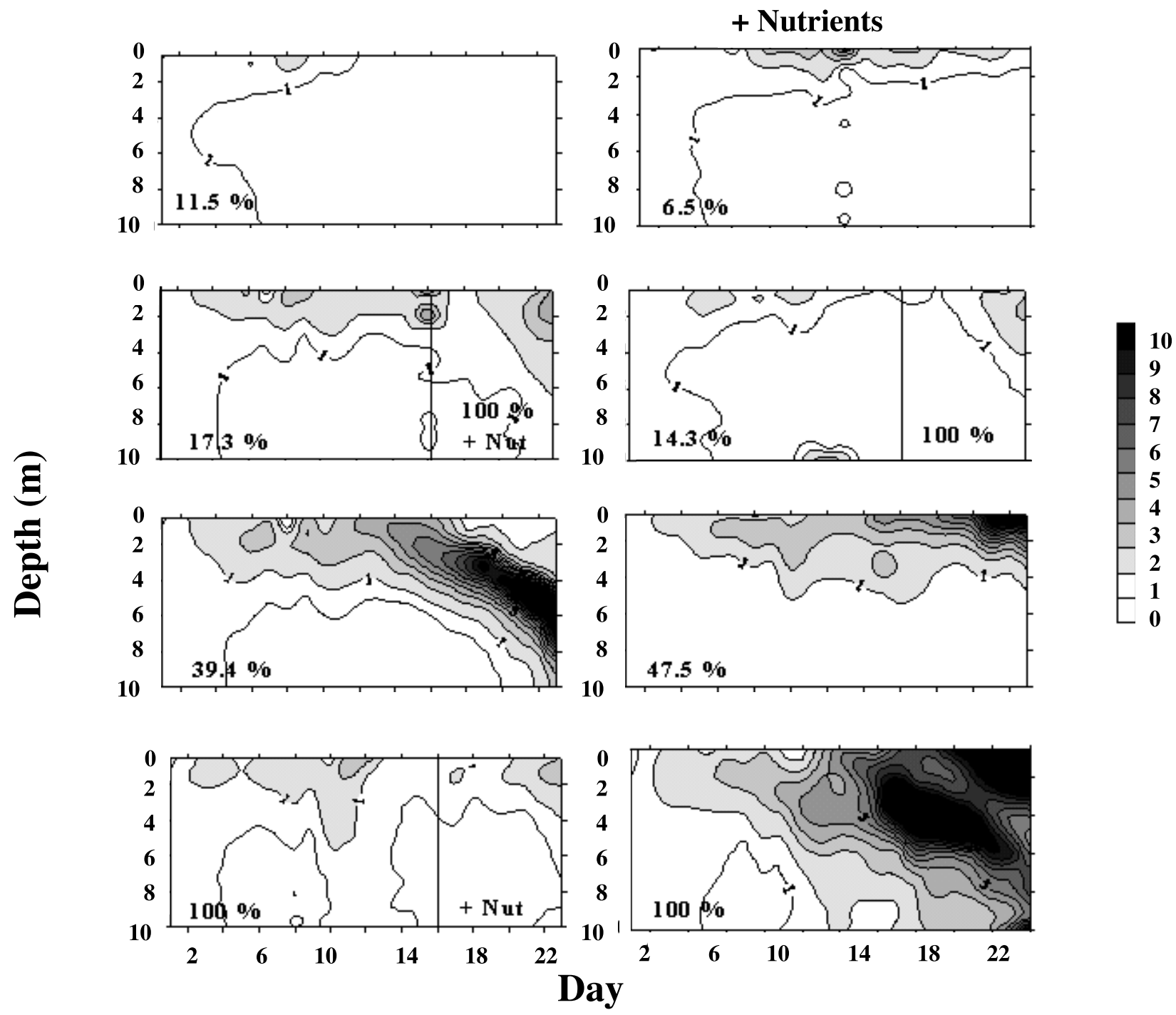

Figure 5. Contour plots showing the development of fluorescence (arbitrary units), derived from daily CTD casts, with depth along the experiment in (left) unamended and (right) nutrient-ammended mesocosms. Vertical solid bars indicate the timing of changes in experimental treatments in the second phase of the experiment, and the resulting treatments are indicated in the plot.

Figures 3 and 4). Indeed, the nutrient-amended phytoplankton community exposed to the full incident irradiance showed a significant tendency (Wilcoxon sign-rank test, $P=0.0002)$ to support a higher chlorophyll $a$ concentration than those communities in the unamended mesocosms at all levels of shading (Figure 3). Hence, the average chlorophyll a concentration increased linearly with increasing percent of incoming irradiance $\left(R^{2}=0.74, P=\right.$ $0.007, N=7$ ), except for the community enclosed in the unamended mesocosm that was exposed to the full ambient irradiance (Figure 4). Examination of fluorescence profiles (Figure 5), showed that phytoplankton was concentrated in surface waters when the mesocosm was strongly shaded, but occurred at intermediate depths of about 4-5 $\mathrm{m}$, where the weak pycnocline was located, in mesocosms with increased nutrient inputs and/or moderate shading (Figure 5).
[18] The community structure changed considerably in response to the experimental treatments (Figure 6) with nanoautotrophs responding to their enclosure. Nanophytoplankton tended to dominated the phytoplanktonic community in most of the mesocosms. They experienced an increase in abundance at the beginning of the experiment (24 January, day 1 of the experiment, Figure 6), replacing the picophytoplanktonic community that had been present in the ambient waters when the mesocosms were filled (on 23 January). Nanophytoplankton, which remained the dominant community in the ambient waters during the time of the experiment, also dominated the mesocosms receiving $10 \%$ of the incident irradiance and represented about $80 \%$ of the biovolume in these mesocosms, whether nutrient-amended or not. Large diatoms prevailed in the communities where biomass increased greatly and were dominated by the presence of Thalassiosira antarctica but Thalassiosira sp. 

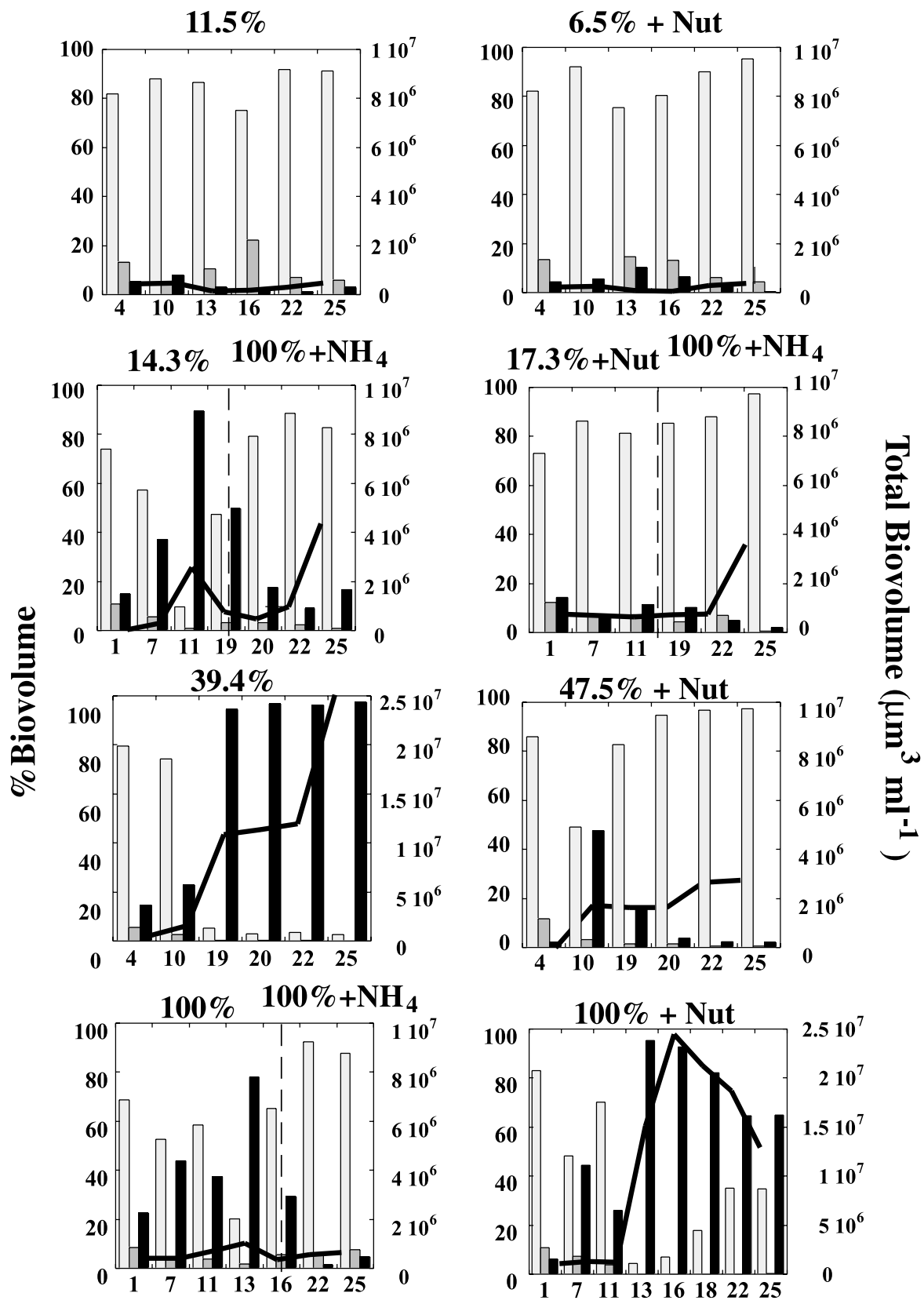

\section{Time (days)}

$\%$ Nanoplankton

\%Microplankton

\%Picoplankton

Figure 6. Changes in the total phytoplankton biovolume (solid line) and in the percent contribution (bars) of pico-, nano-, and microautotrophs to the phytoplankton biovolume during the experiment. The treatment is indicated by the actual percent irradiance resulting from the shading screen and nutrient inputs (+Nut). Vertical dashed lines indicate the timing of shifts in the treatments, with the new treatments indicated above.

Rhizosolenia sp. and Fragilariopsis $s p$. also dominated the phytoplankton biomass of the larger blooms that developed during the experiment (Figures 3 and 6). Average phytoplankton net growth rates increased linearly with increasing irradiance, independently of nutrient inputs, up to levels corresponding to half the ambient irradiance (Table 1 and Figure 4). However, the unamended phytoplankton com- munity receiving the full incident irradiance supported average net growth rates well below those of the moderately shaded mesocosms (Table 1 and Figure 4). Nutrient additions allowed phytoplankton net growth rates to increase continuously throughout the irradiance range (Table 1 and Figure 4), reaching relatively high average net growth rates of $0.64 \pm 0.18$ days $^{-1}$ (maximum net growth rates of up 

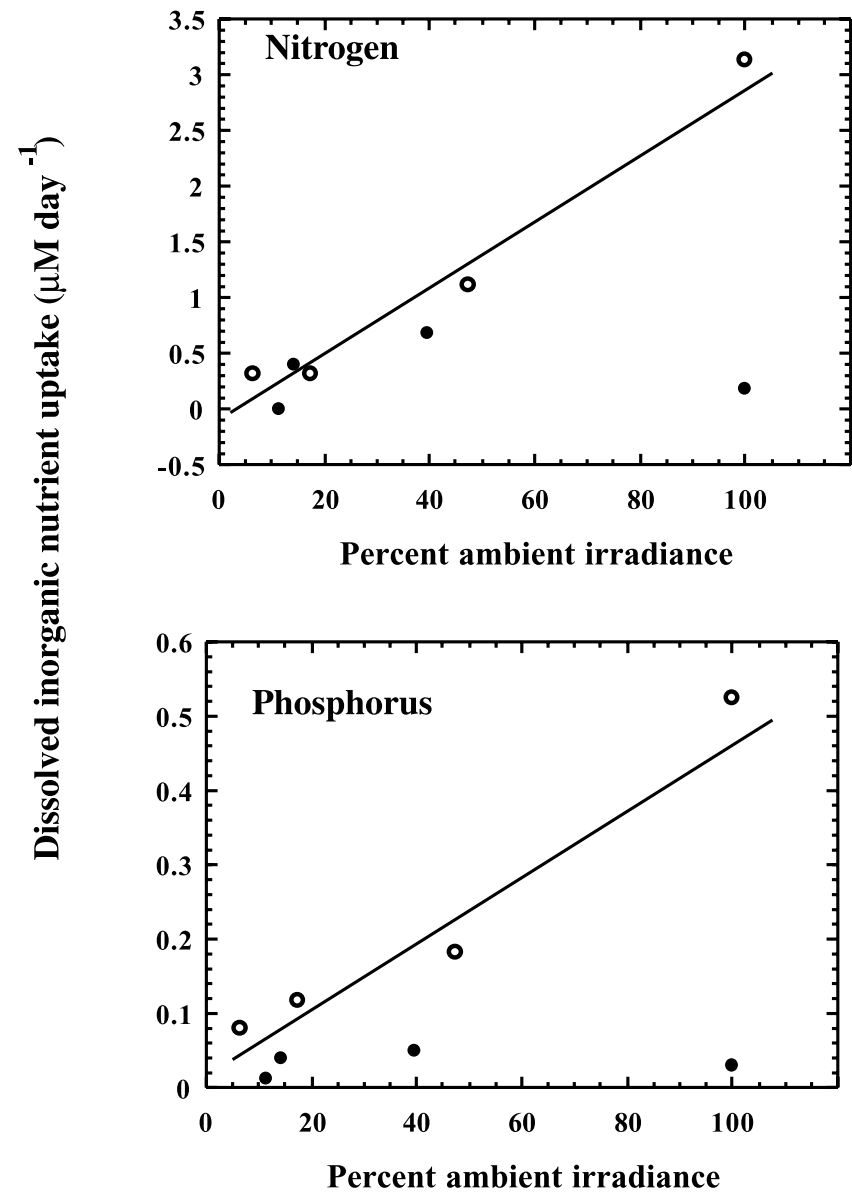

Figure 7. The relationship between the incident irradiance, as percent of the ambient irradiance, and the average net dissolved inorganic nitrogen and phosphorus uptake rate of the experimental phytoplankton communities in mesocosms unamended (solid circles) and receiving nutrient inputs (open circles). The solid line shows the fitted regression line for the mesocosms receiving nutrient inputs.

to 0.81 days $^{-1}$ ) at full ambient irradiance. Hence, growth rates increased significantly with increasing irradiance $\left(R^{2}=0.85, P=0.002, N=7\right)$, except for the community enclosed in the unamended mesocosm exposed to full ambient irradiance, which growth rate was very low (Figure 4), comparable to that in the ambient waters $\left(0.15 \pm 0.15\right.$ days $\left.^{-1}\right)$.

[19] The average net nutrient (dissolved inorganic nitrogen and phosphorous) uptake rates increased linearly with increasing irradiance, independently of nutrient inputs, up to levels corresponding to half the ambient irradiance (Table 1 and Figure 7). However, the phytoplankton community receiving the full ambient irradiance supported net nutrient uptake rates below those of the moderately shaded mesocosms (Figure 7). Nutrient additions allowed net nutrient uptake rates to increase continuously throughout the irradiance range (Figure 7). There was no significant nitrate uptake $\left(0.18 \pm 0.13 \mu \mathrm{M} \mathrm{NO}_{3}\right.$ days $^{-1}$, Ho uptake $=0, t$ test, $P=0.15)$ by the unamended communities exposed to the full ambient irradiance, compared to an important average nitrate uptake rate of $1.21 \pm 0.13 \mu \mathrm{M} \mathrm{NO}_{3}$ days $^{-1}$ when ammonium was added.

[20] The chlorophyll $a$ specific absorption coefficient at $675 \mathrm{~nm}$ of phytoplankton $\left(\mathrm{m}^{2} \mathrm{mg} \mathrm{Chl} a^{-1}\right)$ varied among the mesocosms showing highest values of $0.0175 \pm 0.003$ $($ mean \pm SE) and $0.0134 \pm 0.0017($ mean \pm SE) in the unamended and amended mesocosms respectively of the mesocosms receiving $10 \%$ of the ambient irradiance. The light absorption per unit of chlorophyll $a$ decreased when exposure to irradiance increased, with low average values of the chlorophyll $a$ specific coefficient $\left(\mathrm{m}^{2} \mathrm{mg}\right.$ $\mathrm{Chl} a^{-1}$ ) of $0.0085 \pm 0.001$ (mean \pm SE) and $0.0058 \pm$ 0.0008 (mean $\pm \mathrm{SE}$ ) observed in the mesocosms exposed to full ambient irradiance in the unamended and amended mesocosms, respectively. These results indicate that light harvesting was optimized in the communities growing under shade conditions, and that nutrient additions did not induce important changes in the chlorophyll $a$ light absorption. The normalized UV absorption by MAAs increased with increasing irradiance in unamended mesocosms (Figure 8). Yet, the normalized UV absorption by MAAs in nutrient-amended mesocosms was much smaller than that of unamended mesocosms exposed to similar light levels (Figure 8), suggesting that high-irradiance stress was reduced in communities growing with added silicate, phosphate and ammonia.

[21] To further test, and hence verify the response to increasing irradiance, we removed the shading material from the mesocosms receiving $25 \%$ of the ambient light In this second phase of the experiment, a rapid increase in phytoplankton growth and chlorophyll a concentrations ensued (Table 1 and Figures 3 and 9). The key role of ammonium, was further tested in the second phase of the experiment by supplying ammonium to the growthdepressed community exposed to full ambient irradiance. The shaded (nominal 25\%) communities grew rapidly in

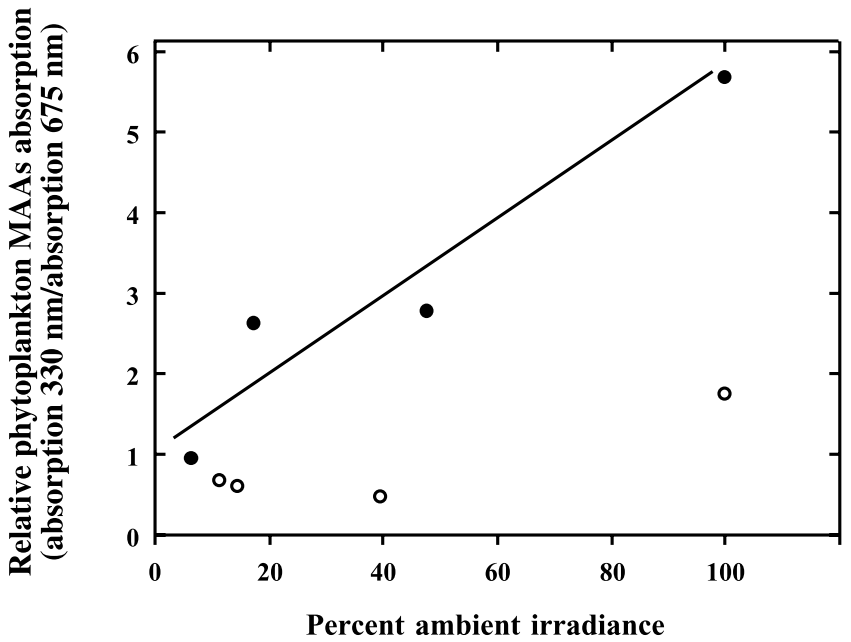

Figure 8. The relationship between the incident irradiance, as percent of the ambient irradiance, and the average normalized absorption by mycosporine-like ammino acids (MAAs) in mesocosms not receiving (solid circles) and receiving nutrient inputs (open circles). The solid line shows the fitted regression line for the mesocosms not receiving nutrient inputs. 

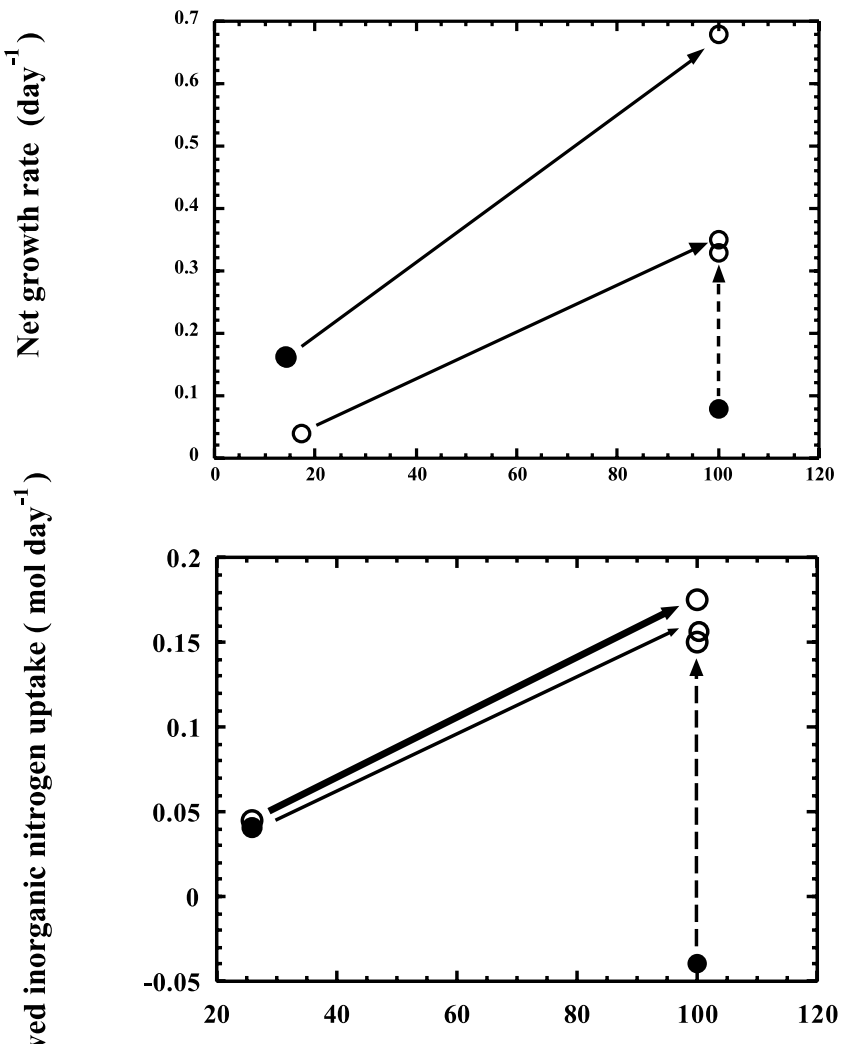

Percent ambient irradiance

[22] The results of the ESEPAC mesocosm experiment suggested that UVR played a role as inhibitor of phytoplankton development in these coastal Antarctic waters. This suggestion was subsequently tested in the small-scale experiment conducted during January 2004. In the treatments where UVR was removed (polycarbonate bottles), chlorophyll $a$ concentration increased to a remarkable extent reaching the highest concentration in the 100\% light (UVR excluded) light treatment, where chlorophyll $a$ was 21 times higher than the initial concentration of $1.06 \pm 0.04 \mu \mathrm{g} \mathrm{Chl} a$ $\mathrm{L}^{-1} 8$ days after the onset of the experiment (Figure 11). Similarly, exclusion of UVR resulted in increased chlorophyll $a$ concentration in the shaded treatments, showing an increase of 16 and 15 times in the 57 and 23\% light treatments, respectively, with respect to the initial chlorophyll $a$ concentration (Figure 11). Treatments exposed to the full solar spectra (quartz bottles) experienced a moderate increase, representing 4, 5.9, and 5.2 times, for the 100,57 , and $23 \%$, treatments respectively (Figure 11 ) relative to the initial chlorophyll $a$ concentration, all well below the increase observed when UVR was filtered out.

[23] Phytoplankton growth rates were also affected by UVR, since growth rates of $0.19 \pm 0.013$ days $^{-1}$ (mean \pm SE) were observed in the treatments exposed to the full solar radiation spectra, half of those obtained in the treatments where UVR was excluded $\left(0.38 \pm 0.016\right.$ days $\left.^{-1}\right)$. Phytoplankton showed the slowest growth rates when growing under $100 \%$ light and full solar spectra $(0.16 \pm$ 0.018 days $^{-1}$ ), however, growth rates in the treatment with similar 100\% light and full solar spectra conditions increased with ammonium additions $\left(0.23 \pm 0.019\right.$ days $^{-1}$, mean $\pm \mathrm{SE})$.

[24] During the small-scale experiment, phytoplankton communities were dominated by photosynthetic nanoflagellates and diatoms, with both phytoplankton groups increasto ammonium additions (dashed line). Solid circles represent unamended mesocosms, and open circles represent mesocosms receiving ammonium inputs. The arrows show the responses to the altered experimental treatments.

response to removal of shading and ammonium inputs. Ammonium inputs stimulated phytoplankton net growth at full ambient irradiance (Figure 9), and reduced their normalized MAAs from the much higher value prior to ammonium additions $(5.67 \pm 1.91$, Figure 8$)$ to a value of $1.97 \pm 0.76$, comparable to those observed at full incident irradiance when nutrient inputs had been provided throughout the experiment $(1.74 \pm 0.25$, Figure 8). Ammonium additions stimulated nitrogen uptake (Figure 9), and also enabled the previously unamended community, which showed no significant nitrate uptake prior to the additions (Figures 7 and 9), to use nitrate (average net uptake $0.68 \pm$ $0.25 \mu \mathrm{M} \mathrm{NO}_{3}$ days $^{-1}$ ). The chlorophyll concentrations did not reach values as high as those in the initial phase of the experiment because of the shorter duration of the observational period. However, the ammonium additions alleviated the photoinhibition which had reduced primary production at high irradiance of the community growing at full ambient irradiance in the previously unamended mescosm (Figure 10).

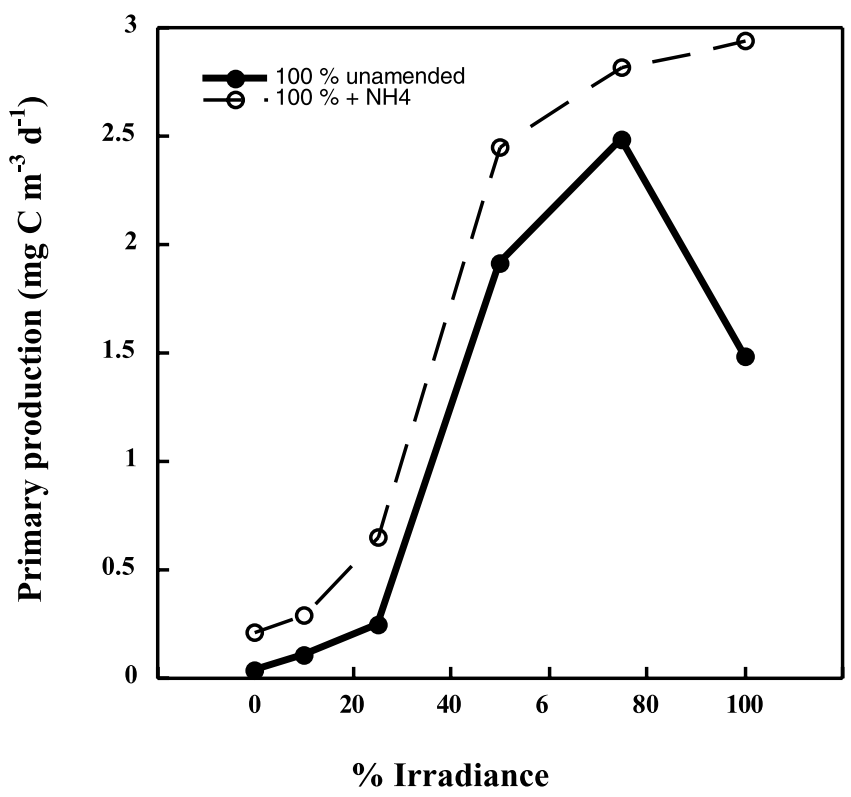

Figure 10. Production-irradiance curves for the phytoplankton community growing in the mesocosm exposed to $100 \%$ irradiance before (solid circles) and after (open circles) ammonium additions during phase II. 


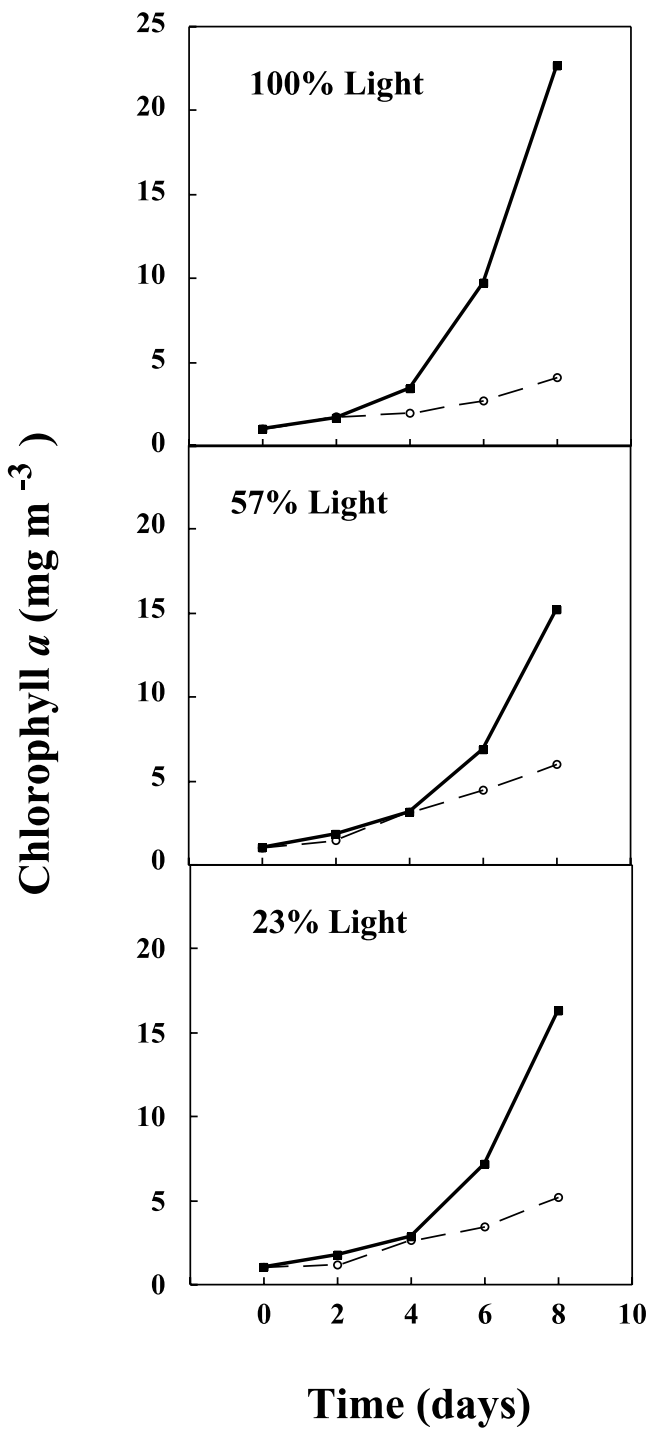

$\rightarrow$ UVR excluded - - ० - Full solar spectra

Figure 11. Chlorophyll $a$ concentration changes with time for the small-scale experiment under three incident irradiances. The dashed lines correspond to the treatments exposed to the full spectra of solar radiation (UVR + PAR, quartz bottles); the solid line data corresponds to the treatments where UVR was filtered out (PAR, polycarbonate bottles).

ing in abundance during the experiments. As observed during the mesocosm experiment, diatoms dominated the biomass in the treatments where phytoplankton biomass was highest. Growth rates of both nanoflagellates and diatoms were affected by light conditions, showing similar growth rates of $0.4 \pm 0.03$ and $0.4 \pm 0.05$ days $^{-1}$ (mean \pm $\mathrm{SE}$, for nanoflagellates and diatoms, respectively) when UVR was excluded. Growth rates were significantly reduced to $0.25 \pm 0.003$ and $0.17 \pm 0.01$ days $^{-1}$ for nanoflagellates and diatoms, respectively, when incubated under full solar spectra. For both phytoplankton groups, the addition of ammonium enhanced growth in the treatments exposed to full solar spectra, i.e., where UVR was not removed. Growth rates in the ammonium-amended treatments increased, relative to unamended treatments, proportionally with increased irradiance (Figure 12), and the growth rates of diatoms increased more than 1.6 times relative to unamended treatments under full solar irradiance (Figure 12). The response to ammonium additions was even greater for flagellates (Figure 12), raising growth rates to nearly twice the growth rates observed at full solar irradiance treatments in the absence of ammonium additions (Figure 12).

\section{Discussion}

[25] The large bloom developed in nutrient-amended mesocosm waters exposed to ambient irradiances was consistent with results from a previous pilot experiment [Agusti and Duarte, 2000]. In both experiments the same species of large diatom Thalassiosira antarctica, became dominant in the community and net phytoplankton growth rate were remarkably similar, 0.317 days $^{-1}$ (calculated over the initial 13 days) and 0.321 days $^{-1}$ in the present and pilot experiments respectively. The growth responses observed are consistent with the high responses of photosynthesis versus irradiance curves already reported [Agawin et al., 2002]. The coherence of these observations provides the necessary evidence that the responses observed in the ESEPAC experiment are reproducible.

[26] The high maximum net growth rates observed in both the current and pilot experiments suggests that other resources, such as iron, do not limit phytoplankton growth rates in the same way as it does in iron-limited sectors of the Southern Ocean [De Baar et al., 1995; De Baar and Boyd, 2000; Gervais et al., 2002; Boyd, 2002]. Indeed, very high iron concentrations of $0.6 \mu \mathrm{mol} \mathrm{Fe} \mathrm{\textrm {L } ^ { - 1 }}$ were measured in the waters of a stream delivering runoff from the Johnson Glacial to the experimental site (Table 2, A. Tovar-Sánchez, unpublished results, 2005). The observations of maximum

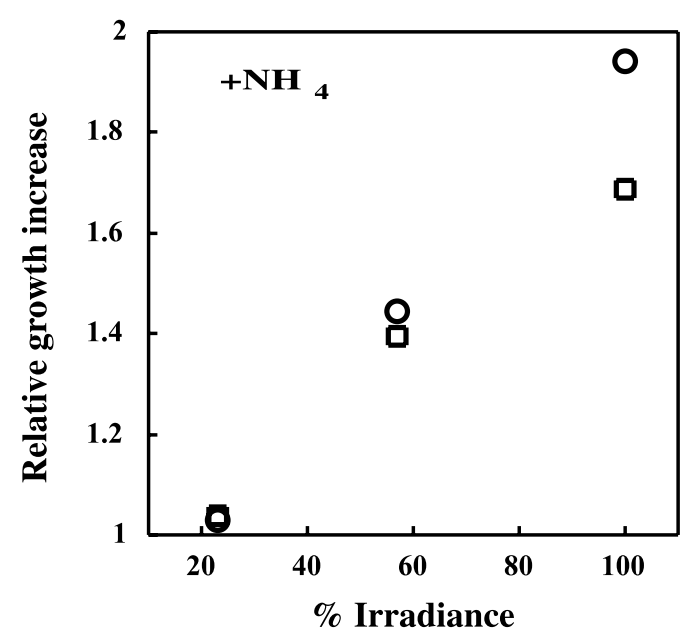

Figure 12. The relationship between the relative increase in growth rates (i.e., growth rates in amended relative to that for unamended treatments) for diatoms (squares) and flagellates (circles) and the incoming irradiance for treatments exposed to the full solar irradiance spectrum at the small-scale experiment. 
Table 2. Literature Data of Nutrients, Chlorophyll $a$ Concentration, and PAR Vertical Attenuation Coefficient From Surface Antarctic Waters Including Coastal Areas ${ }^{\mathrm{a}}$

\begin{tabular}{|c|c|c|c|c|c|c|c|}
\hline & $K_{d}(\mathrm{PAR})$ & $\mathrm{Fe}$ & $\mathrm{NO}_{3}$ & $\mathrm{PO}_{4}$ & $\mathrm{Si}$ & Chla & Reference \\
\hline Weddell Sea (St.5) & & 0.51 & & 1.39 & 85.6 & 0.15 & Sañudo-Wilhelmy et al. [2002] \\
\hline Weddell Sea (St.2) & & 2.15 & & 1.65 & 69.3 & 0.28 & \\
\hline Palmer Station & & 4.47 & & 1.44 & 66.3 & 0.56 & \\
\hline Palmer station & & 6.21 & & 1.33 & 72.4 & 0.42 & \\
\hline Deception Island (South Sethlands Islands) & & 31.0 & & 0.97 & 84.5 & 5.32 & \\
\hline Palmer Station (mean values) & & & 17.74 & 1.05 & 32.16 & 2.27 & Long-Term Ecological Research data archive \\
\hline Observatorio Island (Belingshausen Sea) & & & & & & & Bouchard et al. [2005] \\
\hline 20 February & 0.09 & & 20.16 & 1.56 & 73.04 & 3.02 & \\
\hline 4 March & 0.09 & & 19.06 & 2.30 & 42.90 & 1.04 & \\
\hline Bransfield and Gerlalche Straits & $0.08-0.50$ & & & & & & Figueroa [2002] \\
\hline Ross Sea St. 47 & & 0.25 & 2.3 & 0.44 & 49.6 & & Fitzwater et al. [2000] \\
\hline Ross Sea St. 48 & & 0.22 & 27.1 & 1.93 & 70.3 & & \\
\hline Ross Sea St. One & & 0.07 & 8.3 & 0.38 & 32.0 & & \\
\hline Ross Sea St. 40 & & 0.05 & 16.3 & 1.27 & 62.1 & & \\
\hline Ross Sea St. Nineteen & & 0.09 & 14.6 & 1.20 & 58.6 & & \\
\hline Ross Sea St. Thirty & & 0.08 & 19.2 & 1.49 & 52.2 & & \\
\hline North Drake Passage (St. 1) & & 0.16 & 23.0 & 1.6 & 2.0 & & Martin et al. [1990] \\
\hline South Drake Passage (St. 2) & & 0.16 & 24.8 & 1.78 & 8.8 & & \\
\hline Gerlache Strait (St. 3) & & 7.4 & 23.8 & 2.19 & 74.3 & & \\
\hline Ice & & 25.9 & & & & & \\
\hline Johnson Dock, Livingston Island (South Sethlands) & 0.24 & & 20.0 & 1.7 & 57.3 & 0.72 & Agustí and Duarte [2000] \\
\hline Johnson Dock, Livingston Island (South Sethlands) & 0.35 & $(600)^{\mathrm{b}}$ & 27.5 & 1.6 & 30 & 0.69 & This study \\
\hline
\end{tabular}

net growth rates of up to 0.81 days $^{-1}$, in the presence of grazing and sedimentation losses, in nutrient-amended mesocosms receiving the full irradiance (Table 1 and Figure 3 ), adds to the preceding pilot experiment [Agusti and Duarte, 2000] to further falsify the prediction of a maximum exponential growth rate of about 0.3 days $^{-1}$ for large diatoms growing at the in situ temperature in this study [Mura and Agustí, 1996]. This demonstrates that low temperatures cannot be invoked as a cause for the low phytoplankton growth rates generally observed in the Southern Ocean [Agusti and Duarte, 2000]. The results of the ESEPAC experiment show that reduced irradiance, such as that induced by deep mixing or reduced light penetration by inputs of glacial flour, suppresses phytoplankton growth. Although this result is hardly surprising, the design and scale of the experiment allow quantitative predictions on the level of shading and mixing that would suppress growth. Experimental reduction of the irradiance below 30\% of ambient light levels resulted in a strong suppression of phytoplankton biomass and growth. Because of the turbid nature of the coastal waters where the experiment was conducted, even the underwater light environment in the mesocosms receiving the full irradiance was only comparable, to a mixed layer depth of about $25 \mathrm{~m}$ in open Bransfield Strait waters (average light extinction coefficient, $0.12 \mathrm{~m}^{-1}$, Table 2 [Agawin et al., 2002]).

[27] The experimental reduction of the irradiance generated underwater light environments within the mesocosms that corresponded to those encountered for mixed layer depths of about $30 \mathrm{~m}$ (50\% nominal irradiance reduction), $35 \mathrm{~m}$ (25\% nominal irradiance reduction), and $44 \mathrm{~m}$ (10\% nominal irradiance reduction) in open Bransfield Strait waters. The experimental reduction of irradiance equivalent to a mixed layer depth of $35 \mathrm{~m}$ or deeper, which are often encountered in Antarctic waters around the Antarctic peninsula and elsewhere [Mitchell et al., 1991; Mura and Agustí, 1996; Agawin et al., 2002], strongly suppressed phytoplankton growth. Phytoplankton growth was strongly light limited at light environments comparable to mixed layer depths of $44 \mathrm{~m}$, consistent with predictions that Antarctic phytoplankton blooms cannot develop at mixed layer depths $>40 \mathrm{~m}$ [Sakshaug and Holm-Hansen, 1986]. The 7-10 days lag time for phytoplankton response observed in the mesocosm experiment is comparable to that observed in previous perturbation experiments in the Southern Ocean, such as iron addition experiments [Karsh et al., 2003]. The duration of these lag phases suggest that stress by high irradiance may preclude the development of blooms when the windows of time over which conditions ameliorate are short relative to the lag time (i.e., $<2$ weeks).

[28] Iron-deficient Antarctic phytoplankton communities may be even more susceptible to irradiance reductions than expected from these results, since iron deficiency depresses phytoplankton photosynthetic efficiency, particularly at low irradiance [Geider and LaRoche, 1994]. These results confirm, the important limitation to phytoplankton growth imposed by low-light levels either due to shading in the mesocosms or associated with the deep mixed layer of the Antarctic Peninsula waters and other areas of the Southern Ocean [Mitchell et al., 1991; Mura and Agustí, 1996; Boyd, 2002]. Indeed, an increase in light levels to achieve a more moderate shading of $50 \%$ of the incident ambient irradiance led, without nutrient additions, to the development of an important Thalassiosira antarctica bloom. Strongly lightlimited communities were, dominated by nannophytoplankton, which, by virtue of the small size are more efficient in light capture than are large phytoplankton [Agusti, 1991; Agawin et al., 2002]. Yet, exposure of the phytoplankton 
community to the full ambient irradiance in the absence of nutrient additions led to reduced phytoplankton biomass and growth to levels comparable to those in the ambient waters, suggesting that stress by high irradiance suppressed phytoplankton growth and biomass in the waters with the shallow mixed depth $(4.5 \mathrm{~m})$ where the experiment was conducted.

[29] Evidence of stress due to high-irradiance stress has been documented by reduced survival and the suppression of growth, photosynthesis and nutrient uptake in phytoplankton in laboratory, onboard experiments and through in situ observations [e.g., Karentz et al., 1991; Smith et al., 1992; Keller et al., 1997a, 1997b; Döhler, 1998; Roy, 2000]. The results from the mesocosm experiment presented here, demonstrate that the stress resulting from ambient irradiance levels can suppress nutrient uptake and inhibit bloom development by Antarctic phytoplankton. The inference of high-irradiance stress to phytoplankton is supported by the high relative UV absorption by MAAs by the phytoplankton community that was exposed to the full ambient irradiance in the absence of nutrient additions [e.g., Hernando et al., 2002]. In contrast, nutrient-amended phytoplankton communities showed low relative UV absorption by MAAs independent of the incident irradiance, suggesting that nutrient supply alleviates the stress caused by high irradiance. Indeed, nutrient, particularly ammonium, additions allowed high phytoplankton growth rates and alleviated photoinhibition in phytoplankton exposed to the full ambient irradiance in the mesocosm experiment. Moreover, nutrient additions also allowed light-limited phytoplankton, receiving less than $10 \%$ of the incident irradiance to develop a phytoplankton biomass fivefold higher than that in the unamended mesocosms (Figure 2), suggesting that ammonium additions improve the performance of both lightlimited and light-stressed phytoplankton.

[30] Results from the small-scale experiment were instrumental in validating the inferences from the mesocosm experiment and the small-scale experiment further confirmed both the importance of UV radiation in suppressing phytoplankton growth in the Antarctic coastal waters examined here, and that ammonium additions alleviate this stress and enhance the growth rate of diatoms and photosynthetic flagellates in the presence of UV radiation. This enhancement was observed to increase as total incident irradiance increased. The suppression of phytoplankton growth by UV in the coastal Antarctic waters that has been demonstrated here is consistent with the maintenance of extremely highUV levels over the Southern Ocean due to ozone depletion, which remains a serious issue in the region [Weatherhead and Andersen, 2006].

[31] Nutrient concentrations are very high in Antarctic waters, which represent a paradigm of high-nutrient, lowchlorophyll waters (Table 2). Iron is deficient across most of the Southern Ocean, but shows high concentrations in coastal waters of the Bransfield Strait (Table 2) [e.g., Martin et al., 1990; De Baar and Boyd, 2000; Sañudo-Wilhelmy et al., 2002; Fitzwater et al., 2000], where melting glaciers deliver important amounts of iron-rich volcanic ashes derived from the activity of the volcano at Deception Island (Figure 1) [Agustí and Duarte, 2000; Sañudo-Wilhelmy et al., 2002]. Johnson's Dock receives high-iron inputs from the Johnson Glacial, as indicated the high concentration of
$0.6 \mu \mathrm{mol} \mathrm{Fe} \mathrm{L}^{-1}$ measured in a sample from a stream delivering runoff from the Johnson Glacial into the bay (Table 2, A. Tovar-Sánchez, unpubished results, 2005). This value is orders of magnitude above the values of $0.1 \mathrm{nmol}$ $\mathrm{Fe} \mathrm{L}^{-1}$ characteristic of Fe-deficient Antarctic waters and so iron deficiency cannot account for the high-nutrient and low-chlorophyll nature of the waters at Johnson's Dock (Table 2). Other coastal Antarctic waters, such as the Weddell and Ross Seas also receive iron inputs from materials delivered from melting glacials and icebergs [Ducklow et al., 2006; Smith et al., 2007], but our study seems to have provided the first (indirect) evidence that the ambient iron concentrations may be able to alleviate iron stress in coastal phytoplankton in the S. Ocean.

[32] While dissolved inorganic nitrogen concentrations in coastal Antarctic waters are very high (Table 2), these are dominated by nitrate ( $~ 98 \%$ of DIN) and ammonium concentrations remain low, much as they do elsewhere in the Southern Ocean [e.g., Biggs et al., 1985; Bianchi et al., 1997; Priddle et al., 1997; Agustí and Duarte, 2000]. Ammonium represents, however, a more favorable nitrogen source for phytoplankton under the conditions of both light limitation and high-irradiance stress that may affect phytoplankton growth in the Southern Ocean. Ammonium uptake is energetically more efficient than nitrate uptake [Syrett, 1981; Dortch, 1990], so that ammonium supply may improve the performance of light-limited phytoplankton using ammonium versus nitrate as the nitrogen source. Exposure to high irradiance, particularly to high UV, is associated with photooxidative stress in phytoplankton, and a loss of the reducing capacity required to assimilate nitrate [Döhler, 1998]. Hence, nitrate uptake should be more sensitive to high irradiance than is ammonium uptake [Döhler, 1998]. Indeed, Antarctic phytoplankton is characterized by low specific nitrate uptake rates [Dugdale and Wilkerson, 1991]. A comparison between the net rate of decline in dissolved inorganic nitrogen $\left(3.14 \mu \mathrm{M} \mathrm{N}_{\text {days }}{ }^{-1}\right)$ versus that of ammonium $\left(0.84 \mu \mathrm{M} \mathrm{N}\right.$ days $\left.^{-1}\right)$ after nutrient additions were discontinued, demonstrated that ammonium inputs alleviated high irradiance stress and allowed the phytoplankton to use nitrate, because, on average, $74 \%$ of the nitrogen uptake by ammonium-amended communities exposed to full sunlight was supported by existing nitrate. Whereas bacteria could also be responsible for some of the net $\mathrm{N}$ use, this is likely to be a minor fraction, as the biomass and production of bacteria showed a very modest response to the experimental treatments compared to that of phytoplankton [cf. Duarte et al., 2005].

[33] The results obtained in the second phase of the mesocosm experiment, along with those derived from the subsequent small-scale experiment, provided further evidence of the positive effects that nutrient additions had on phytoplankton growth and nutrient uptake rates at high irradiance, which were associated with the supply of ammonium. Ammonium additions alleviated the stress to phytoplankton caused by high irradiance as evidenced by a reduction in relative MAAs absorption to levels similar to the amended communities, and the alleviation of photoinhibition following ammonium inputs. The alleviation of the highirradiance stress by ammonium additions stimulated the growth rate in both the mesocosm and small-scale experiments and the nutrient uptake (both ammonium and nitrate) 
of the previously unamended community, providing evidence of a key role of ammonium inputs in allowing phytoplankton stressed by high irradiance to resume growth and nutrient use.

[34] The results presented confirm the notion that light plays a paramount role in regulating phytoplankton growth and bloom development in iron-sufficient Antarctic coastal waters. Reduced light levels, such as those resulting from deep mixing, limit phytoplankton growth, whereas excess irradiance also suppresses phytoplankton growth [e.g., Boyd, 2002]. Thus development of extensive Antarctic phytoplankton blooms requires both adequate resource supply and sufficient cloud cover or vertical mixing to effectively reduce exposure to stressing irradiance levels, while still providing an adequate underwater light field. The fastest phytoplankton growth rates and largest blooms should be achieved in the presence of ammonium at supply rates sufficient to alleviate high-irradiance stress, and stimulate nitrate and phosphate use.

[35] Although other studies report a important role for nitrate in the nitrogen nutrition of Antarctic phytoplankton [Sweeney et al., 2000], the key role of ammonium reported here is coherent with previous indications that ammonium supports most of the phytoplankton nitrogen uptake in the Southern Ocean [Biggs et al., 1985], and helps explain why ammonia concentrations are so low $(<1 \mu \mathrm{M})$ compared to the high-nitrate concentrations $(30 \mu \mathrm{M})$ in Antarctic waters [Biggs et al., 1985; Bianchi et al., 1997; Priddle et al., 1997; Agusti and Duarte, 2000]. Ammonium has been traditional thought of as an inhibitor of nitrate uptake by phytoplankton, although the experimental evidence for this seems equivocal [cf. Dortch, 1990]. Indeed, our results suggest that ammonium additions facilitate, rather than suppress, nitrate uptake, particularly at high irradiance. Ammonium is largely supplied by recycling by metazoans, suggesting that the intense ammonium inputs associated to krill megaswarm activity [Quentin et al., 1994] may seed the conditions for subsequent phytoplankton blooms. The finding that ammonium supply enhances nitrate uptake at high irradiance further suggests that stimulation of phytoplankton due to ammonium excretion by mesozooplankton may overcompensate for the grazing losses required to support their excretion, possibly leading to complex feedback relationships between phytoplankton and their grazers. The findings reported here support predictions derived from observations of diel cycles of ammonium concentration in the Southern Ocean, which could only be explained if phytoplankton growth rates exceeded 0.5 days $^{-1}$ and was supported by ammonium as the dominant nitrogen source [Priddle et al., 1997].

[36] The results from the large-scale experiment presented confirm the complex regulation of phytoplankton growth in coastal Antarctic waters, by resource limitation, such as iron limitation, light limitation during winter and the periods of intense mixing [e.g., Mitchell et al., 1991; Mura and Agustí, 1996], light dispersion by glacial flour [Agustí and Duarte, 2000]; high-irradiance stress, and other factors, such as grazing pressure [Smith et al., 2000; Moline et al., 2004; Boyd, 2002]. These multiple controls result in a narrow window of environmental conditions conducive to the development of phytoplankton blooms, as indicated by the highly skewed frequency distribution of chlorophyll $a$ in the Southern Ocean [Sullivan et al., 1993; Arrigo et al., 1998]. Moreover, high-irradiance stress on phytoplankton seems to induce long (7-10 days) lags in the responses following amelioration of growth conditions, implying that windows of improved conditions for growth need to be relatively long (e.g., 2 weeks) to yield phytoplankton blooms. The conditions necessary to trigger phytoplankton blooms may, however, differ among phytoplankton taxa and groups, accounting for the dominance of small-sized algae (picoand nanoplankton) under strongly shaded or light-stressed conditions observed in the experiment.

[37] Adequate conditions to trigger phytoplankton blooms are more frequently met in the coastal zone, where iron levels are high [Martin et al., 1990; De Baar and Boyd, 2000; Sañudo-Wilhelmy et al., 2002] and ammonium supply may be more intense, as evidenced by the more frequent occurrence of large blooms in these locations [Sullivan et al., 1993; Arrigo et al., 1998; Ducklow et al., 2006]. Adequate conditions may be also found under other particular circumstances such as the fertilization of Weddell Sea and Antarctica Peninsula waters by iron released from large icebergs [Smith et al., 2007]; the very high ammonium concentrations $(>150 \mu \mathrm{M})$ that develop within sea ice brine channels. The latter may explain the very large diatom biomass found within the ice [Thomas and Dieckmann, 2002], and the release of ammonium as the sea ice melts has also been linked to the development of phytoplankton blooms at the ice edge [Biggs et al., 1985].

\section{Conclusion}

[38] In summary, the results presented here provide evidence of the role of resource limitation and stress, rather than intrinsic limitations to growth, on the regulation of phytoplankton growth and bloom development in Antarctic coastal waters. These results confirm the power of combined large-scale and small-scale experimental approaches to test complex set of factors that explain the prevalence of high-nutrient, low-chlorophyll conditions even in ironsufficient coastal areas of the Southern Ocean.

[39] Acknowledgments. The ESEPAC experiment was funded by the Antarctic program of the Spanish Plan Nacional de I + D (ANT97-0273). We thank C. Cordón, commander of the R/V Hespérides; the crew, particularly manouver and diver personnel, for their skilled assistance during the logistically complex ESEPAC experiment; the UGBO personnel involved in the experiment for professional technical assistance; and all scientists participating in the ESEPAC experiment for their contribution. We thank K. Flynn, T. Frazer, S. Hernández, and R. Rivkin for useful comments; C. Barrón and L. Sevillano for nutrient analyses; S. Loureiro for flow cytometric analysis; A. Tovar-Sánchez for unpublished iron concentration data; and M. Bañón and J. I. Díaz for radiation data. Data from the Palmer LTER data archive were supported by Office of Polar Programs, NSF Grants OPP-9011927, OPP-9632763 and OPP-0217282.

\section{References}

Agawin, N. S. R., S. Agustí, and C. M. Duarte (2002), Abundance of Antarctic picophytoplankton and their response to light and nutrient manipulation, Aquat. Microbial Ecol., 29, 161-172, doi:10.3354/ ame 029161 .

Agustí, S. (1991), Allometric scaling of light absorption and scattering by phytoplankton cells, Can. J. Fish. Aquat. Sci., 48, 763-767, doi:10.1139/ f91-091.

Agustí, S., and C. M. Duarte (2000), Experimental induction of a large phytoplankton bloom in Antarctic coastal waters, Mar. Ecol. Prog. Ser., 206, 73-85, doi:10.3354/meps206073. 
Arrigo, K. R. (1994), Impact of ozone depletion on phytoplankton growth in the Southern Ocean: Large-scale spatial and temporal variability, Mar Ecol. Prog. Ser., 114, 1-12, doi:10.3354/meps114001.

Arrigo, K. R., D. Worthen, A. Schnell, and M. P. Lizotte (1998), Primary production in Southern Ocean waters, J. Geophys. Res., 103, 15,58715,600, doi:10.1029/98JC00930.

Banaszak, A. T. (2003), Photoprotective physiological and biochemical responses of aquatic organisms, in UV Effects in Aquatic Organisms and Ecosystems, edited by E. W. Helbling and H. Zagarese, pp. 329356, R. Soc. of Chem., Cambridge, U. K.

Bianchi, M., F. Feliatra, F. P. Tréguer, M. A. Vincendeau, and J. Morvan (1997), Nitrification rates, ammonium and nitrate distribution in upper layers of the water column and in sediments of the Indian sector of the Southern Ocean, Deep Sea Res. Part II, 44, 1017-1032, doi:10.1016/ S0967-0645(96)00109-9.

Biggs, D. C., A. F. Amos, and O. Holm-Hansen (1985), Oceanographic studies of epi-pelagic ammonium distributions: The Ross Sea $\mathrm{NH}_{4}$ flux experiment, in Antarctic Nutrient Cycles and Food Webs, edited by W. R. Siegfried, P. R. Condy, and R. M. Laws, pp. 93-103, Springer-Verlag, Heidelberg, Germany.

Bouchard, J. N., R. Suzanne, G. Ferreyra, D. A. Campbell, and A. Curtosi (2005), Ultraviolet-B effects on photosystem II efficiency of natural phytoplankton communities from Antarctica, Polar Biol., 28, 607-618, doi:10.1007/s00300-005-0727-4.

Boyd, P. W. (2002), Environmental factors controlling phytoplankton processes in the Southern Ocean, J. Phycol., 38, 844-861, doi:10.1046 j.1529-8817.2002.t01-1-01203.x.

Boyd, P. W., et al. (2000), A mesoscale phytoplankton bloom in the polar Southern Ocean stimulated by iron fertilization, Nature, 407, 695-702, doi:10.1038/35037500.

Cullen, J. J., J. P. Neale, and M. P. Lesser (1992), Biological weighting function for the inhibition of phytoplankton photosynthesis by ultraviolet radiation, Science, 258, 646-650, doi:10.1126/science.258.5082.646.

De Baar, H. J. W., and P. W. Boyd (2000), The role of iron in plankton ecology and carbon dioxide transfer in the global, in The Changing Ocean Carbon Cycle, edited by R. B. Hanson, H. W. Ducklow, and J. G. Field, pp. 61-140, Cambridge Univ. Press, Cambridge, U. K.

De Baar, H. J. W., J. T. M. De Jong, D. C. E. Bakker, B. M. Loscher C. Veth, U. V. Bathmann, and V. S. Smetacek (1995), Importance of iron for plankton blooms and carbon dioxide drawdown in the Southern Ocean, Nature, 373, 412-415, doi:10.1038/373412a0.

Döhler, G. (1998), Effects of ultraviolet radiation on pigmentation and nitrogen metabolism of Antarctic phytoplankton and ice algae, J. Plant Physiol., 153, 603-609.

Dortch, Q. (1990), The interaction between ammonium and nitrate uptake in phytoplankton, Mar. Ecol. Prog. Ser., 61, 183-201, doi:10.3354/ meps061183.

Duarte, C. M., J. M. Gasol, and D. Vaqué (1997), The role of experimental approaches in marine microbial ecology, Aquat. Microbial Ecol., 13 , 101-111, doi:10.3354/ame013101

Duarte, C. M., S. Agustí, D. Vaqué, N. S. R. Agawin, J. Felipe, E. O Casamayor, and J. M. Gasol (2005), Experimental test of bacteriaphytoplankton coupling in the Southern Ocean, Limnol. Oceanogr. $50,1844-1854$.

Ducklow, H. W., W. Fraser, D. M. Karl, L. B. Quetin, R. M. Rossd, R. C. Smith, S. E. Stammerjohne, M. Vernet, and R. M. Daniels (2006), Watercolumn processes in the West Antarctic Peninsula and the Ross Sea: Interannual variations and foodweb structure, Deep Sea Res. Part II, 53, 834-852, doi:10.1016/j.dsr2.2006.02.009.

Dugdale, R. C., and F. P. Wilkerson (1991), Low specific nitrate uptake rate: A common feature of high-nutrient, low-chlorophyll marine ecosystems, Limnol. Oceanogr., 36, 1678-1688.

El-Sayed, S. Z., D. C. Biggs, and O. Holm-Hansen (1983), Phytoplankton standing crop, primary productivity, and near-surface nitrogenous nutrient fields in the Ross Sea, Antarctica, Deep Sea Res., 30, 871-886, doi:10.1016/0198-0149(83)90005-5.

Figueroa, F. L. (2002), Bio-optical characteristics of Gerlache and Bransfield Strait waters during an Antarctic summer cruise, Deep Sea Res. Part II, 49, 675-691, doi:10.1016/S0967-0645(01)00118-7.

Fitzwater, S. E., K. S. Johnson, R. M. Gordon, K. H. Coale, and W. O. J. Smith (2000), Trace metal concentration in the Ross Sea and their relationship with nutrients and phytoplankton growth, Deep Sea Res. Part II, 47, 3159-3179, doi:10.1016/S0967-0645(00)00063-1.

Geider, R. J., and J. LaRoche (1994), The role of iron in phytoplankton photosynthesis and the potential of iron-limitation of primary productivity in the sea, Photosynthesis Res., 39, 275-301, doi:10.1007/ BF00014588.

Gervais, F., U. Riebesell, and M. Y. Gorbunov (2002), Changes in primary productivity and chlorophyll a in response to iron fertilization in the Southern Polar Frontal Zone, Limnol. Oceanogr., 47, 1324-1335.
Hansen, K., and F. Koroleff (1999), Detemination of nutrients, in Methods of Seawater Analysis, edited by K. Grasshoff, K. Kremling, and M. Ehrhardt, pp. 159-228, Wiley, Weinheim, Germany.

Hernando, M. P., I. J. Carreto, M. O. Carignan, G. A. Ferreyra, and C. Gross (2002), Effects of solar radiation on growth and micosporinelike amino acids content in Thalassiosira sp.: An Antarctic diatom, Polar Biol., 25, 12-20, doi:10.1007/s003000100306.

Holm-Hansen, O., S. Z. El-Sayed, G. A. Franceschini, and R. L. Cuhel (1984), Primary production and the factors controlling phytoplankton growth in the southern ocean, in Marine Phytoplankton and Productivity, edited by O. Holm-Hansen and R. Gilles, pp. 11-50, Springer-Verlag, Berlin.

Karentz, D., J. E. Cleaver, and D. L. Mitchell (1991), Cell survival characteristics and molecular responses of Antarctic phytoplankton to ultraviolet-B radiation, J. Phycol., 27, 326-341, doi:10.1111/j.00223646.1991.00326.x.

Karsh, K. L., T. W. Trull, M. J. Lourey, and D. M. Sigman (2003), Relationship of nitrogen isotope fractionation to phytoplankton size and iron availability during the Southern Ocean Iron Release Experiment (SOIREE), Limnol. Oceanogr., 48, 1058-1068.

Keller, A. A., P. Hargraves, H. Jeon, Klein-MacPhee, G. Klos, C. Oviatt, and J. Zhang (1997a), Ultraviolet-B radiation enhancement does not affect marine trophic levels during a winter spring bloom, Ecoscience, 4, 129-139

Keller, A. A., P. Hargraves, H. Jeon, Klein-MacPhee, G. Klos, C. Oviatt, and J. Zhang (1997b), Effects of ultraviolet-B enhancement on marine trophic levels in a stratified coastal system, Mar. Biol. Berlin, 130, $277-$ 287, doi:10.1007/s002270050247.

Kérouel, R., and A. Aminot (1997), Fluorometric determination of ammonia in sea and estuarine waters by direct segmented flow analysis, Mar. Chem., 57, 265-275, doi:10.1016/S0304-4203(97)00040-6.

Martin, J. H., R. M. Gordon, and S. E. Fitzwater (1990), Iron in Antarctic waters, Nature, 345, 156-158, doi:10.1038/345156a0.

Mitchell, G. J., E. A. Brody, O. Holm-Hansen, C. McClain, and J. Bishop (1991), Light limitation of phytoplankton biomass and macronutrient utilization in the Southern Ocean, Limnol. Oceanogr., 36, 1662-1677.

Moline, M. A., H. Claustre, T. K. Frazer, O. S. Schofield, and M. Vernet (2004), Alteration of the food web along the Antarctic Peninsula in response to a regional warming trend, Global Change Biol., 10, $1973-$ 1980, doi:10.1111/j.1365-2486.2004.00825.x.

Mura, M. P., and S. Agustí (1996), Growth rates of diatoms from coastal Antarctic waters estimated by in situ dialysis incubation, Mar. Ecol. Prog. Ser., 144, 237-245, doi:10.3354/meps 144237.

Nelson, D. M., and W. O. J. R. Smith (1991), Sverdrup revisited: Critical depths, maximum chlorophyll levels, and the control of Southern Ocean productivity by the irradiance-mixing regime, Limnol. Oceanogr., 36, $1650-1661$

Parsons, T. R., Y. Maita, and C. M. Lalli (1984), A Manual of Chemical and Biological Methods for Seawater Analysis, Pergamon, Oxford, U. K.

Priddle, J., M. J. Whitehouse, A. Atkinson, A. S. Brierley, and E. J. Murphy (1997), Diurnal changes in near-surface ammonium concentrationInterplay between zooplankton and phytoplankton, J. Plankton Res., 19, 1305-1330, doi:10.1093/plankt/19.9.1305.

Quentin, L. B., R. M. Ross, and A. Clarke (1994), Krill energetics: Seasonal and environmental aspects of the physiology of Euphasia superba, in Southern Ocean Ecology: The BIOMASS Perspective, edited by S. Z. El-Sayed, pp. 165-184, Cambridge Univ. Press, Cambridge, U. K

Riegger, L., and D. Robinson (1997), Photoinduction of UV-absorbing compounds in Antarctic diatoms and Phaeocystis Antarctica, Mar. Ecol. Prog. Ser., 160, 13-25, doi:10.3354/meps160013.

Roy, S. (2000), Strategies for the minimisation of UV-induced damage, in The Effects of UV Radiation in the Marine Environment, edited by S. de Mora, S. Demers, and M. Vernet, pp. 176-236, Cambridge Univ. Press, Cambridge, U. K

Sakshaug, E., and O. Holm-Hansen (1986), Photoadaptation of Antarctic phytoplankton: Variations in growth rate, chemical composition and $\mathrm{P}$ versus I curves, J. Plankton Res., 8, 459-473, doi:10.1093/plankt/ 8.3.459.

Sañudo-Wilhelmy, S. A., K. A. Olsen, J. M. Scelfo, T. D. Foster, and A. R. Flegal (2002), Trace metal distributions off the Antarctic Peninsula in the Weddell Sea, Mar. Chem., 77, 157-170, doi:10.1016/S03044203(01)00084-6.

Smith, K. L., B. H. Robison, J. J. Helly, R. S. Kaufmann, H. A. Ruhl, T. J. Shaw, B. S. Twining, and M. Vernet (2007), Free-drifting icebergs: Hot spots of chemical and biological enrichment in the Weddell Sea, Science, 317, 478-482, doi:10.1126/science. 1142834

Smith, R. C., et al. (1992), Ozone depletion: Ultraviolet radiation and phytoplankton biology in Antarctic waters, Science, 255, 952-958, doi: $10.1126 /$ science. 1546292 
Smith, W. O., Jr., J. Marra, M. R. Hiscock, and R. T. Barber (2000), The seasonal cycle of phytoplankton biomass and primary productivity in the Ross Sea, Antarctica, Deep Sea Res. Part II, 47, 3119-3140, doi:10.1016/S0967-0645(00)00061-8

Sullivan, C. W., K. R. Arrigo, C. R. McClain, J. C. Comiso, and J. Firestone (1993), Distributions of phytoplankton blooms in the Southern Ocean, Science, 262, 1832-1837, doi:10.1126/science.262.5141.1832.

Sweeney, C., et al. (2000), Nutrient and carbon removal ratios and fluxes in the Ross Sea, Antarctica, Deep Sea Res., 47, 3395-3421, doi:10.1016/ S0967-0645(00)00073-4.

Syrett, P. J. (1981), Nitrogen metabolism in microalgae, in Physiological Metabolism of Phytoplankton Ecology, edited by T. Platt, pp. 182-210, Can. Gov. Publ. Cent., Ottawa.
Thomas, D. N., and G. S. Dieckmann (2002), Antarctic sea ice a habitat for extremophiles, Science, 295, 641-644, doi:10.1126/science.1063391.

Weatherhead, E. C., and S. B. Andersen (2006), The search for signs of recovery of the ozone layer, Nature, 441, 39-45, doi:10.1038/ nature 04746 .

N. S. R. Agawin, Department of Biology, University of the Islas Baleares, Carretera de Valldemossa Km 7.5, E-07122 Palma, Spain.

S. Agustí, C. M. Duarte, and M. Llabrés, Instituto Mediterráneo de Estudios Avanzados, CSIC-UIB, C/ Miquel Marqués 21, E-07190 Esporles, Spain. (sagusti@uib.es)

H. Kennedy, School of Ocean Sciences, Bangor University, Menai Bridge LL59 5AB, UK. 